\title{
1. PETROLOGY AND GEOCHEMISTRY OF GABBROIC AND RELATED ROCKS FROM SITE 894, HESS DEEP1
}

\author{
R.B. Pedersen, ${ }^{2}$ J. Malpas,${ }^{3}$ and T. Falloon ${ }^{4}$
}

\begin{abstract}
The petrogenesis of gabbroic rocks and associated basaltic dikes recovered at Ocean Drilling Program Site 894 has been evaluated using petrography, mineral chemistry, and bulk-rock chemistry as well as Nd isotope analyses. The igneous lithologies recovered at Site 894 include gabbronorite, gabbro, olivine gabbro, olivine gabbronorite, and basalt. The gabbroic rocks and the crosscutting dikes show similar isotope and trace elements signatures, and they are therefore suggested to be cogenetic. The trace element data indicate that the rocks formed from a highly depleted parental magma. Isotopic compositions of Site 894 rocks are within the range of mid-ocean-ridge basalt, and similar to gabbroic rocks recovered from Site 895 .

The gabbroic rocks show no systematic variation in mineral compositions downhole, but exhibit large variations on a local scale. Plagioclase compositions, for example, vary by up to 25 mole percent An in a single thin section. The rare earth element contents vary by 1 order of magnitude, which is close to the total range seen in the crustal section of many ophiolite complexes. There is, however, no systematic, large-scale variation in bulk-rock compositions downhole. The downhole variations are characterized by abrupt (meter scale) variations in compatible and incompatible trace element contents.

There appears to be a decoupling in the behavior of incompatible and compatible trace elements in the gabbroic rocks. $\mathrm{Cr}$ shows a well-defined trend when plotted against Ca\# whereas $\mathrm{TiO}_{2}$ and $\mathrm{Zr}$ do not. The lack of any correlation between $\mathrm{TiO}_{2}$ and $\mathrm{Zr}$ with $\mathrm{Ca}$ numbers suggests that the abundance of oxides and incompatible element-bearing phases such as zircon and apatite (which is present in the rocks) is unrelated to the composition of the silicate matrix. The local enrichments of incompatible elements in rocks that are relatively rich in compatible elements indicate that the geochemistry of the Site 894 gabbros is not controlled by mineral crystallization and fractionation alone.

We suggest that the Site 894 rocks formed along the roof of the magma reservoir where a sequence of mesocumulates and basaltic gabbros developed owing to limited buoyancy-driven migration of interstitial melts. Late magmatic liquids migrated locally into the almost-crystallized matrix. These late magmatic liquids enriched the rocks in incompatible elements but had little influence on the distribution of compatible trace elements and major elements in the rocks. The trace element geochemistry of the rocks may be understood in terms of fractional crystallization and various mixing processes.
\end{abstract}

\section{INTRODUCTION}

During the last few years, with increasingly detailed imaging of the seismic structure of the oceanic crust and field mapping and geochemical sampling of the plutonic sections of ophiolite suites, it has become clear that our view of a simple layer-cake stratigraphy of the oceanic crust is somewhat naive. This layer-cake relationship was interpreted by some to have formed from a single large-scale and long-lived magma chamber beneath the spreading ridge axis, but no such chamber has ever been imaged by seismic reflection in any ocean basin. The model was driven by the evidence then at hand from ophiolitic gabbros and cumulate ultramafic rocks and has since been severely modified by detailed investigations in a number of complexes, notably Troodos in Cyprus (e.g., Malpas, 1990) and Semail in Oman (e.g., Nicolas et al., 1988). The plutonic sections of these ophiolites, and others such as the Karmøy ophiolite in Norway (Pedersen, 1986), clearly formed from relatively small ephemeral magma chambers that show mutually intrusive relationships and in which the rocks are deformed simultaneously with magmatic activity in a spreading

'Mével, C., Gillis, K.M., Allan, J.F., and Meyer, P.S. (Eds.), 1996. Proc. ODP, Sci. Results, 147: College Station, TX (Ocean Drilling Program).

${ }^{2}$ Geologic Institute, University of Bergen, Allégaten 41, N-5007, Bergen, Norway. rolf.pederson@geol.uib.nc

Centre for Earth Resources Research, Memorial University, St. John's, Newfoundland AlB 3X5, Canada.

${ }^{4}$ Department of Geology, University of Tasmania, GPO Box 252C, Hobart, Tasmania 7001, Australia environment. However, because it is impossible to measure the spreading rate at which ophiolites were formed with any degree of certainty, it has been difficult to determine how the internal stratigraphy of the oceanic crust is influenced by the rate of spreading, the magma supply, and the degree of magmatic vs. amagmatic spreading. For this reason, it is important to obtain samples of the plutonic section (Layer 3 ) of the oceanic crust by deep drilling in areas that have experienced different spreading rates, for example, slow spreading on the Southwest Indian Ridge (Leg 118, Hole 735B) and fast spreading on the East Pacific Rise (Leg 147, Sites 894 and 895). The results of drilling at Hole 735B have been reported elsewhere (Von Herzen et al., 1991) and are used here in part for comparative purposes. In late 1992 to early 1993, a series of offset holes was drilled by the Ocean Drilling Program (ODP) at Hess Deep to investigate the evolution of a mid-equatorial section of the East Pacific Rise.

Hess Deep, in the eastern equatorial Pacific, is the deepest portion of an oceanic rift valley that is propagating westward into the eastern flank of the East Pacific Rise ahead of the Cocos-Nazca spreading center. At a distance of some $70 \mathrm{~km}$ east of the East Pacific Ridge axis, the propagating spreading center has built a median ridge in the rift valley with a relief of as much as $2700 \mathrm{~m}$. A complete but structurally dissected crustal section of the East Pacific Rise including peridotites, gabbroic rocks, diabases, and basaltic volcanic rocks has been sampled from the floor of Hess Deep and this intrarift ridge during a number of submersible cruises and by ODP Leg 147 at Sites 894 and 895 . The distribution of these rock types indicates that there is severe structural dismemberment of the crustal and upper mantle stratigraphy. There appears to be little lateral continuity and, in places, an apparent reversal of normal lithospheric stratigraphy reveals harzburgites of the upper mantle sequence overlying cumulate gab- 
bros of Layer 3. In addition, the western portion of the ridge is dominated by gabbros and gabbronorites, and the eastern end by diabases and basalts from higher in the stratigraphic sequence.

During Leg 147, two sites, Sites 894 and 895, were drilled at Hess Deep to investigate the evolution of the magma supply to the sub-rift magma chamber system of the fast-spreading East Pacific Rise. A sequence of high-level gabbroic rocks was recovered from Site 894, located at the western end of the intrarift ridge. At Site 895, approximately $9 \mathrm{~km}$ southeast of Site 894, a sequence of ultramafic and mafic rocks was recovered, including dunites and harzburgites with associated troctolites, gabbros, and basalts. Rocks from Site 894 were considered by the shipboard party to have developed in the roof zone of an axial magma chamber, and those from Site 895 from the transition zone between Layer 3 of the oceanic crust and the upper mantle. Here, we report the results of subsequent petrological and geochemical investigations conducted on samples collected from the two most significant holes at Site 894, Holes $894 \mathrm{~F}$ and $894 \mathrm{G}$. Drilling at Hole $894 \mathrm{~F}$ penetrated $25.7 \mathrm{~m}$ below seafloor (mbsf) and recovered $1.8 \mathrm{~m}$ of deformed and cataclasized gabbros and olivine gabbros cut by aphyric basaltic dikes. Hole $894 \mathrm{G}$, drilled $10 \mathrm{~m}$ west of Hole $894 \mathrm{~F}$, penetrated $154.5 \mathrm{mbsf}$ and recovered $45.78 \mathrm{~m}$ of core. In this hole, the upper $18.6 \mathrm{~m}$ was not cored as an equivalent section was recovered in Hole $894 \mathrm{~F}$.

Together, Holes $894 \mathrm{~F}$ and $894 \mathrm{G}$ represent significant penetration into the upper parts of Layer 3 of the oceanic crust. Compared with the rocks recovered during ODP Leg 118 at Hole 735B on the Southwest Indian Ridge, those cored at Site 894 at Hess Deep represent plutonic rocks clearly from the upper parts of a magma chamber operating in a spreading system with twice the spreading rate. The igneous lithologies recovered in Holes $894 \mathrm{~F}$ and $894 \mathrm{G}$ are gabbronorite, gabbro, olivine gabbro, olivine gabbronorite, and basalt. On a handsample scale, the textures displayed by these rocks are equivalent to those of the varitextured gabbros found in ophiolites generally toward the upper boundary of the plutonic sequence and immediately below the sheeted dikes. Indeed, this is the most likely location of Site 894 , albeit in the highly structurally dissected crustal stratigraphy exhibited at Hess Deep. Although recognized widely in ophiolite sequences, these rocks have only rarely been worked on in any detail (Pedersen, 1986), and have never been collected in significant quantities from the ocean basins. An understanding of their petrology and origin is key to understanding the processes by which magma moves in the upper part of sub-rift magma chambers to potentially form the dikes and volcanic rocks of oceanic Layer 2.

\section{PETROGRAPHY}

\section{Gabbroic Rocks}

The characteristic feature of the gabbroic rocks is their abrupt change in grain size, texture, and modal mineralogy on a hand-sample scale. This variety of textures is not regular, and grain sizes vary from pegmatitic to aphanitic over short distances; hence, the term "varitextured" has been employed (Pedersen and Malpas, 1984). In earlier ophiolite literature, they have been referred to as isotropic gabbros, but this is a misnomer because they may indeed exhibit structural features, as is the case at Hess Deep.

Gabbronorites represent the most voluminous rock type recovered at Site 894 and grade by a reduction in their modal orthopyroxene content to gabbros. Many of them exhibit poikilitic textures with anhedral oikocrysts of orthopyroxene and minor clinopyroxene, containing chadacrysts of resorbed olivine with which there exists a reaction relationship. In places, intergranular texture is exhibited by subhedral plagioclases and smaller interstitial clinopyroxenes, and elsewhere, hypidiomorphic granular textures were recognized. Indeed, all textures gradational between this variety of types were recognized. Some gabbronorites are clearly more plagioclase rich than others, and elsewhere, there is sporadic enrichment of $\mathrm{Fe}$-Ti oxides.
These latter rocks and other gabbronorites that are among the more coarse-grained samples are particularly interesting in that they are in places characterized by concentrations of zircon and apatite (PI. 1). Both of these minerals are associated with primary oxide minerals and dark green amphibole that are considered to be late magmatic or deuteric. Clusters of euhedral rhombic and acicular zircons are in places intergrown with the associated oxide minerals. Smaller concentrations of acicular or stubby apatite are typically partly enclosed by the amphibole, suggesting co-crystallization from an evolved fluid-rich silicate magma. These patches with concentrated accessory minerals represent the most evolved compositions sampled at Site 894.

Other patches or lenses of equigranular gabbronorite are found alternating with poikilitic gabbronorites in several sections of the core, giving the impression of textural layering. Both textural types are examples of those found in classic cumulate complexes, most particularly adcumulates. Elsewhere, magmatic foliation defined by the alignment of plagioclase is developed, especially in the lower parts of Hole $894 \mathrm{G}$. The foliated rocks occur sporadically, and, although they generally grade from equigranular gabbronorites of a similar grain size, elsewhere they are in sharp contact with unfoliated coarse poikilitic gabbronorites. The foliation itself is best developed in poikilitic rocks of medium grain size, which, however, are virtually devoid of orthopyroxene and are properly referred to as gabbros. Microscopic examination of the sharp contact relationships between the foliated and nonfoliated rocks shows that the foliation is clearly inclined to the contact, suggesting that the coarse, unfoliated gabbronorites are crosscutting veins (PI. 2). Although in the preliminary stages of our investigation we believed that magma flow through this part of the oceanic crust was possibly controlled by a filter-pressing mechanism that produced both the foliation and these veins, we now recognize on the basis of arguments made below that this is not the complete story.

Another texture of particular interest and recognizable only in thin section occurs as 1- to 3-mm patches in some of the medium-grained poikilitic gabbronorites. These small areas exhibit ophitic to subophitic textures and appear to define inclusions of diabase within the surrounding gabbronorite (PI. 3). Clinopyroxene is replaced in part by amphibole, the inclusion boundaries are ill-defined, and they are considered to be partially resorbed. Such a feature would not be out of place at the upper margin of a magma chamber in contact with overlying sheeted dikes. Indeed, if partially hydrated and altered diabase inclusions were resorbed by the gabbroic rocks, it would be a mechanism of releasing water into the magmatic system, allowing for a significant build-up of volatiles in later stages of crystallization and promotion of amphibole and oxide precipitation under pneumatolytic conditions (see Gillis, this volume).

\section{Basaltic Dikes}

The gabbroic section in Hole $894 \mathrm{G}$ is cut by two basaltic dikes. Both are porphyritic, with up to $15 \%$ phenocrysts of plagioclase, olivine, and $\mathrm{Cr}$-spinel. The upper dike displays well-developed subophitic texture; the lower is considerably more glassy with well-developed spherulites, which are quenched against the adjacent gabbronorite (Pl. 4). This lower dike is flow differentiated, with marked phenocryst concentration within $0.5 \mathrm{~cm}$ of the contact. Plagioclase microlites are flow aligned parallel to the dike contact.

\section{MINERALOGY AND MINERAL CHEMISTRY}

Analyses of plagioclase, orthopyroxene, clinopyroxene, and olivine were conducted on a Cameca superprobe in energy-dispersive mode for major elements and wavelength-dispersive mode for minor elements. Multiple points were analyzed for each phase, both in individual crystals and throughout each thin section. Most figures pre- 
sented herein plot average analyses of cores from mineral phases except where noted. Full data tables are available for more than 1000 mineral analyses on request from the authors.

\section{Plagioclase}

In both gabbronorites and gabbros, apart from local accumulations in a few samples, plagioclase forms approximately $50 \%$ to $55 \%$ of the mode. Most plagioclases are subhedral, lathe-shaped crystals but are more euhedral in those coarse-grained rocks in which plagioclase forms as much as $75 \%$ of the mode. The average grain size of plagioclase throughout the cored section varies from 1 to $8 \mathrm{~mm}$ and increases slightly with depth in Hole $894 \mathrm{G}$. The magmatic foliation recognized in the middle and lower parts of Hole $894 \mathrm{G}$ is marked by the alignment of tabular plagioclase crystals (Pl. 2).

Plagioclase is generally the least altered of the silicate minerals, and care was taken to report analyses of the freshest igneous compositions. Optical zoning is common and can be normal, reverse, oscillatory, or patchy in nature (Pl. 5). Sharp and gradational contacts between the zones are present. In detail, compositional zoning varies from one crystal to another in the same thin section and is characterized by a range of $\mathrm{An}$ contents from $\mathrm{An}_{87}$ to $\mathrm{An}_{44}$ as confirmed by microprobe analysis. Although normal zoning is the most common, in a few cases rims are clearly more calcic than cores. Although there are variations between plagioclases in single thin sections (up to 25 mole percent An), there is little change in the overall average An content of the plagioclase cores downhole, although more albitic compositions occur more commonly at depth in Hole 894G, particularly between 60 and 108 mbsf (Fig. 1). In rocks that are clearly enriched in plagioclase, the An content of plagioclase cores is markedly higher than the norm, reaching values of $A n_{88}$ in individual crystals. The average An content of plagioclase cores is compared to the downhole $\log$ of bulk-rock (b.r.) $\mathrm{CaO}$ (wt\%) and Eu\# in Figure 1. The Eu\#'s are computed using Eu\# $=\left(\mathrm{Eu}^{*} /\left[\mathrm{Sm}^{*}+\mathrm{Gd}^{*}\right] \times 0.5\right)-1$, where $\mathrm{Eu}^{*}$, $\mathrm{Sm}^{*}$, and $\mathrm{Gd}^{*}$ represent chondrite-normalized values. The index shows the degree of Eu anomalies in the rocks, with positive and negative numbers reflecting positive and negative Eu anomalies, respectively. Relatively good correlation is seen: where Eu\# and $\mathrm{CaO}$ (b.r.) are higher than average, An content of the plagioclase is generally high. Significant low Eu\#'s are clearly marked in rocks where plagioclase is most albitic.

In the dikes, plagioclase phenocrysts are tabular and subhedral and may be intergrown with altered olivine. Compositions vary from $\mathrm{An}_{70}$ to $\mathrm{An}_{85}$, and plagioclases with both normal and reverse zoning occur. Samples from the diabase dike encountered at $30 \mathrm{mbsf}$ in Hole $894 \mathrm{G}$ have positive Eu anomalies, $\mathrm{CaO}$ content of approximately 12 $\mathrm{wt} \%$, and more calcic plagioclases than the accompanying gabbros and gabbronorites (Fig. 1).

\section{Ferromagnesian Minerals}

Major element compositions of orthopyroxenes, clinopyroxenes, and olivines are presented in Figure 2. In terms of major elements, the ferromagnesian minerals in the gabbroic rocks appear to be equilibrium assemblages.

\section{Orthopyroxene}

In the Site 894 gabbronorites, orthopyroxene occurs in amounts up to $20 \%$ of the mode as either large anhedral oikocrysts or as euhedral to subhedral, granular primocrysts. Both forms are strongly pleochroic from $\mathrm{x}=$ pale pink, $\mathrm{y}=$ pale yellow, to $\mathrm{z}=$ pale green, and they appear unzoned. In some thin sections, the crystals are embayed and almost everywhere exhibit exsolution lamellae of clinopyroxene. In the poikilitic rocks, chadacrysts are either olivine or plagioclase. Although the exsolution lamellae make it difficult to analyze the orthopyroxenes, no difference is discernible between the compositions of the oikocrysts and primocrysts. It is apparent that the $\mathrm{Mg}$ content of the orthopyroxenes is relatively constant with depth (average $\mathrm{En}_{68}$ ) except for values as low as $\mathrm{En}_{61}$ at $76.79 \mathrm{mbsf}$ and $\mathrm{En}_{63.5}$ at 100.23 mbsf. These lows correspond to low bulk-rock Mg\#'s and low Mg\#'s in coexisting clinopyroxenes (Fig. 3). Apart from these intervals, there is no clear indication of pyroxene compositional response to processes such as magma fractionation or replenishment. The more iron-rich hypersthenes occur in coarse-grained gabbronorites along with sodic plagioclase, zircon, apatite, and iron-titanium oxide minerals. They are therefore thought to have crystallized from (or reequilibrated with) relatively evolved interstitial liquid that had accumulated in patches at these depths.

The $\mathrm{Cr}$ and $\mathrm{Ti}$ contents of the orthopyroxenes are similar to orthopyroxenes in other oceanic gabbronorites, but neither show a clear fractionation trend when plotted against $\mathrm{Mg}$. With $\mathrm{Ti}$, this may be the result of varying cooling rate, which has a direct effect on the partition coefficient (Coish and Taylor, 1979; Gamble and Taylor, 1980) and may provide for a range of $\mathrm{Ti}$ values at constant $\mathrm{Mg}$. This decoupling of the major and minor element chemistry is marked throughout Hole $894 \mathrm{G}$ and may indicate different rates of diffusion for different elements, and thus variable degrees of chemical equilibrium. Such features are also apparent from Figure 4, in which $\mathrm{Ti}$ and $\mathrm{Cr}$ in the pyroxenes and bulk-rock $\mathrm{Ti}$ and $\mathrm{Cr}$ are plotted with depth. In the rocks there tends to be an antipathy between $\mathrm{Cr}$ and $\mathrm{Ti}$, but such is not the case in individual pyroxenes. $\mathrm{Cr}$, a compatible element in this system, generally follows the bulk-rock pattern, but $\mathrm{Ti}$ as an incompatible element appears more random. This pattern more likely reflects the amount of coprecipitating oxide phases as well as a lack of equilibrium between pyroxene and interstitial liquid.

\section{Clinopyroxene}

Clinopyroxene occurs throughout the sequence in Hole $894 \mathrm{G}$ with an average modal abundance of $32 \%$. It, like orthopyroxene, occurs as oikocrysts and as anhedral equigranular crystals together with plagioclase. Clinopyroxene is weakly zoned with core to rim values between $\mathrm{En}_{81}$ and $\mathrm{En}_{70}$, and an average core composition of $\mathrm{En}_{73}$. More evolved clinopyroxene core compositions $\left(\mathrm{En}_{59}\right)$ occurring in a gabbronorite at 106.7 mbsf correspond to a low $\mathrm{Mg} \#$ in the bulk rock but little decrease in the En value of coexisting orthopyroxenes (Fig. 3). The occurrence of numerous thin exsolution lamellae of orthopyroxene and incipient alteration along cleavage planes to amphibole, even in the freshest samples, makes analysis difficult. $\mathrm{Cr}$ and $\mathrm{Ti}$ contents of the clinopyroxenes are quite variable, with $\mathrm{Cr}$ showing a sympathetic relationship with bulk-rock $\mathrm{Cr}$ content, but $\mathrm{Ti}$ much less so (Fig. 4), as with the orthopyroxenes. Likewise, there is no evolutionary trend exhibited by these trace elements and $\mathrm{Mg}$ content of the clinopyroxenes. Overall values of $\mathrm{Cr}$ and $\mathrm{Ti}$ are comparable to other oceanic gabbros (Figs. 5, 6). Compared to rocks collected during Leg 118 on the Southwest Indian Ridge, Hole 894G clinopyroxenes form a field between Hole 735B gabbros and gabbronorites with a wide range of $\mathrm{TiO}_{2}$ at relatively constant $\mathrm{Mg}$ content.

Mg\#'s of the dikes and their clinopyroxenes are comparable to those of the surrounding gabbroic rocks.

\section{Olivine}

Pale yellow to colorless olivine occurs sporadically throughout the gabbro-gabbronorite sequence in amounts up to $10 \%$ of the mode. It is generally highly altered with anhedral, resorbed morphologies either rimmed by orthopyroxene or occurring as chadacrysts enclosed within large orthopyroxene oikocrysts. Forsterite content varies from $\mathrm{Fo}_{63}$ to $\mathrm{Fo}_{71}$ (average $\mathrm{Fo}_{65.5}$ ), and there is only minor variation in $\mathrm{NiO}$, which shows no consistent relationship with forsterite.

Although somewhat altered, olivine phenocrysts in the basaltic dikes are variably resorbed and embayed, but have preserved cores of 


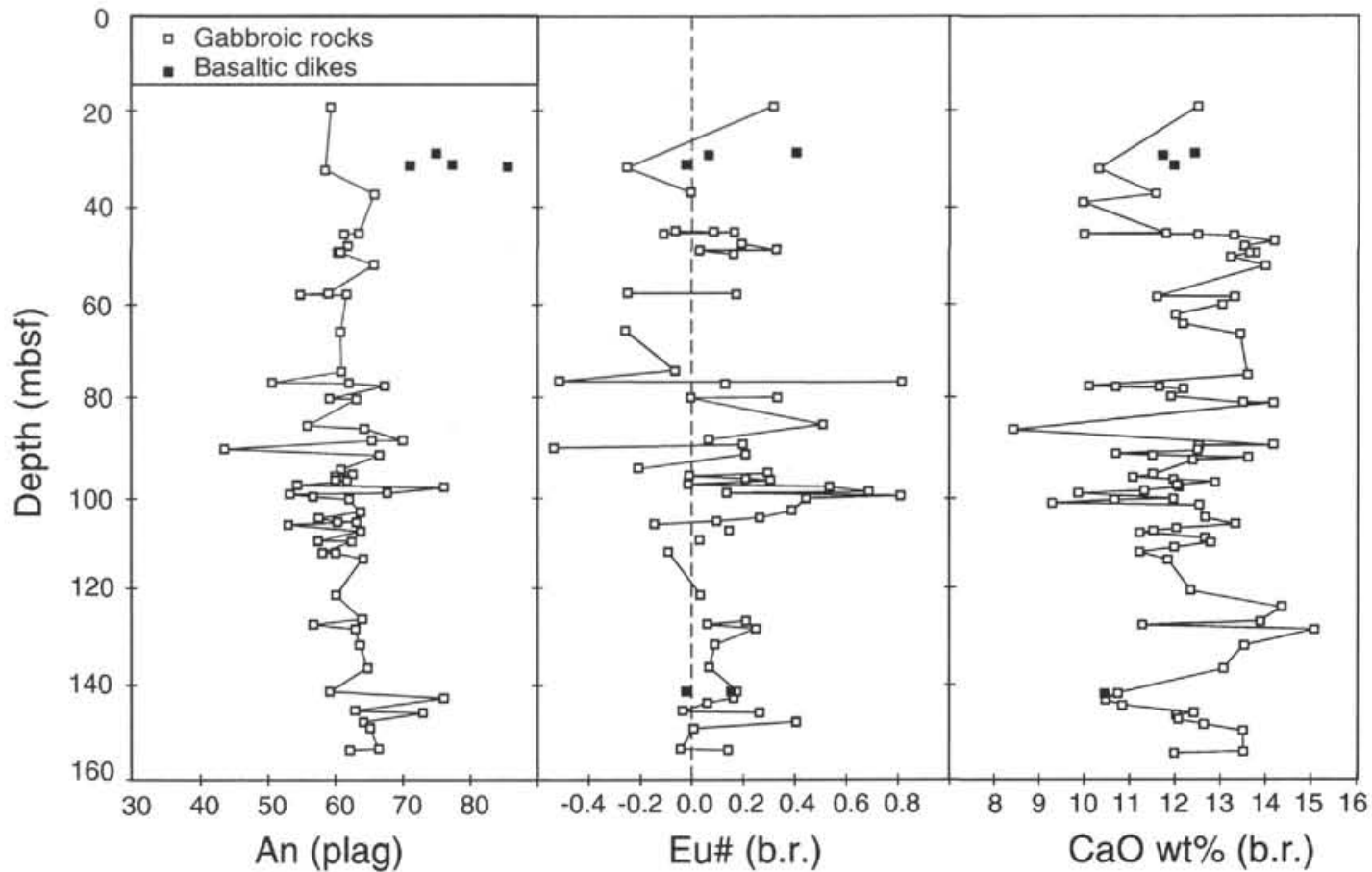

Figure 1. Variation of An content of plagioclase compared to calculated Eu anomaly (Eu\#) and $\mathrm{CaO}$ content of the host bulk rock (b.r.) against stratigraphic depth.

average $\mathrm{Fo}_{88}$. Ni contents of these olivines are likewise higher than in the surrounding gabbros.

\section{Amphibole and Other Late Magmatic Phases}

According to Gillis (this volume), most of the amphiboles in the Hole $894 \mathrm{G}$ rocks lie in a compositional range between actinolite and magnesio-hornblende. $\mathrm{CaO}$ and $\mathrm{FeO}$ increase sympathetically and although the $\mathrm{Al}^{\mathrm{IV}}$ content increases with site A occupancy and Ti content, there is no consistent variation in composition with depth or the morphological nature (i.e., groundmass, isolated crystal, rimming, or replacing clinopyroxene) and mixtures of low- $\mathrm{Al}$ and high- $\mathrm{Al}$ amphiboles are not uncommon. Gillis has conducted rare-earth-element (REE) analyses of both zircon and apatite that show classic chondrite-normalized distributions.

\section{BULK-ROCK CHEMISTRY}

Major and trace elements were determined by X-ray fluorescence (XRF) spectrometry (Philips PW 1404) at the University of Bergen using glass beads and pressed-powder pellets, respectively. Sixtyfour samples were analyzed for REE at the University of Bristol by ICP-MS. Analyses of international standards show that the relative uncertainties are better than $3 \%$ for the REE. Representative analyses are listed in Table 1 and full data tables are available for almost 100 whole-rock samples on request from the authors.

\section{Interelement Variations}

\section{Gabbroic Rocks}

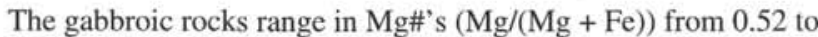
0.32 (Fig. 7). This is a considerably larger range than that shown by the mafic silicate phases, and may be because of an additional effect of oxides on the bulk-rock Mg\#'s. The range in Mg\#'s of the Site 894 samples is less than the range reported from the gabbroic rocks that were recovered from Hole $735 \mathrm{~B}$ in the Indian Ocean $(0.88$ to 0.32$)$

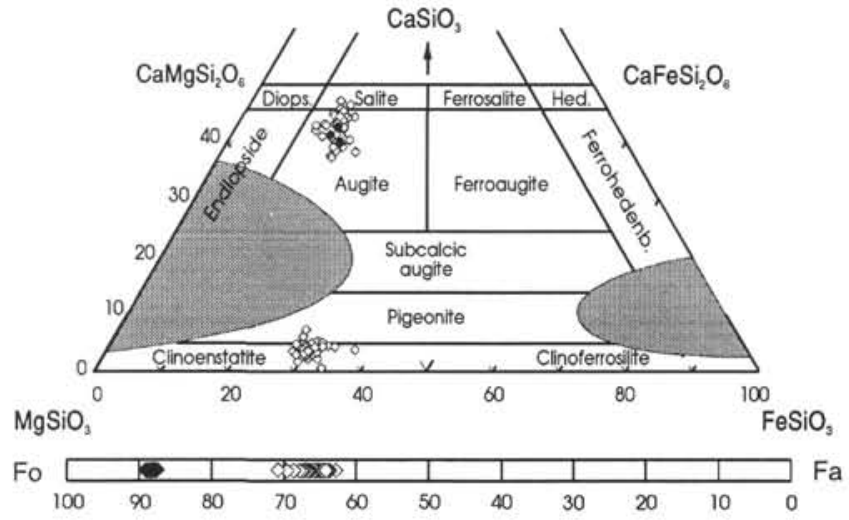

Figure 2. Major element chemistry of olivines and pyroxenes from Hole 894G.

(Von Herzen et al., 1991). The gabbroic rocks from Hess Deep do not show any enrichment in $\mathrm{SiO}_{2}$ with decreasing $\mathrm{Mg \# s}$. There seems, on the contrary, to be slightly lower $\mathrm{SiO}_{2}$ contents in the most evolved rocks relative to the bulk of the gabbros (Fig. 7). The Ca\#'s ( $\mathrm{Ca} /[\mathrm{Ca}$ + Na]) decrease slightly with decreasing Mg\#'s, but show only onehalf the range exhibited by the $\mathrm{Mg}$ \#'s. $\mathrm{TiO}_{2}$ and $\mathrm{P}_{2} \mathrm{O}_{5}$ both show in-

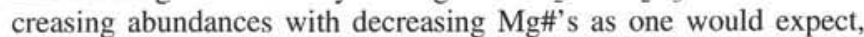
and the enrichments appear to follow exponential trends (Fig. 7). The samples from Hess Deep have considerably lower $\mathrm{TiO}_{2}$ contents than the plutonic rocks recovered from Hole 735B (maximum values of approximately $3 \%$ and $8 \%$, respectively).

The variations in compatible and incompatible trace elements against Mg\#'s are shown in Figure 7. With decreasing Mg\#'s there is a decrease in $\mathrm{Cr}$ and $\mathrm{Ni}$ from 600 to $100 \mathrm{ppm}$ and 300 to $50 \mathrm{ppm}$, respectively. The trends are relatively poorly defined, particularly at low levels where rocks with similar incompatible element abundances show a wide range in Mg\#'s. Incompatible elements like $\mathrm{Nd}$ and $\mathrm{Zr}$ increase, as would be expected, with a decrease in the bulk-rock 


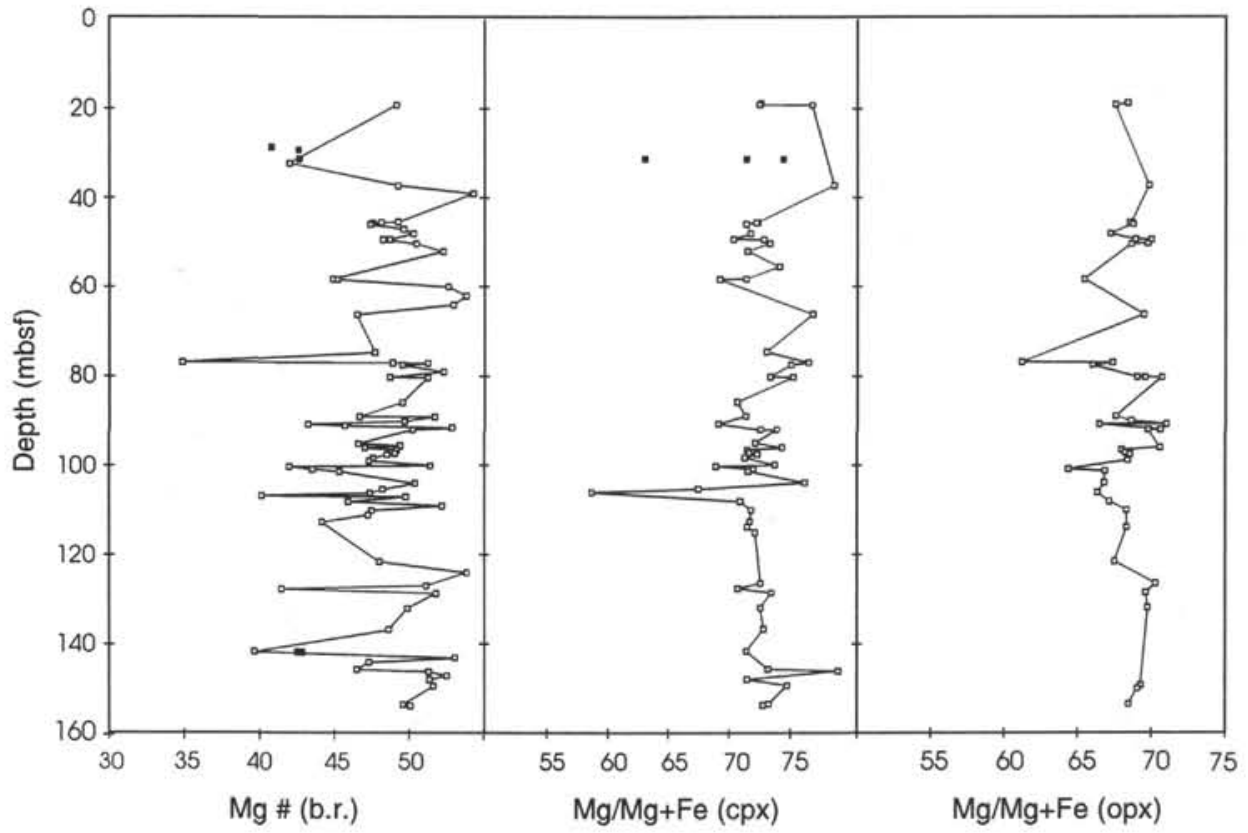

Figure 3. Variation in Mg\# for bulk rock, clinopyroxene (cpx), and orthopyroxene (opx) with depth in Hole 894G. Symbols as in Figure 1.

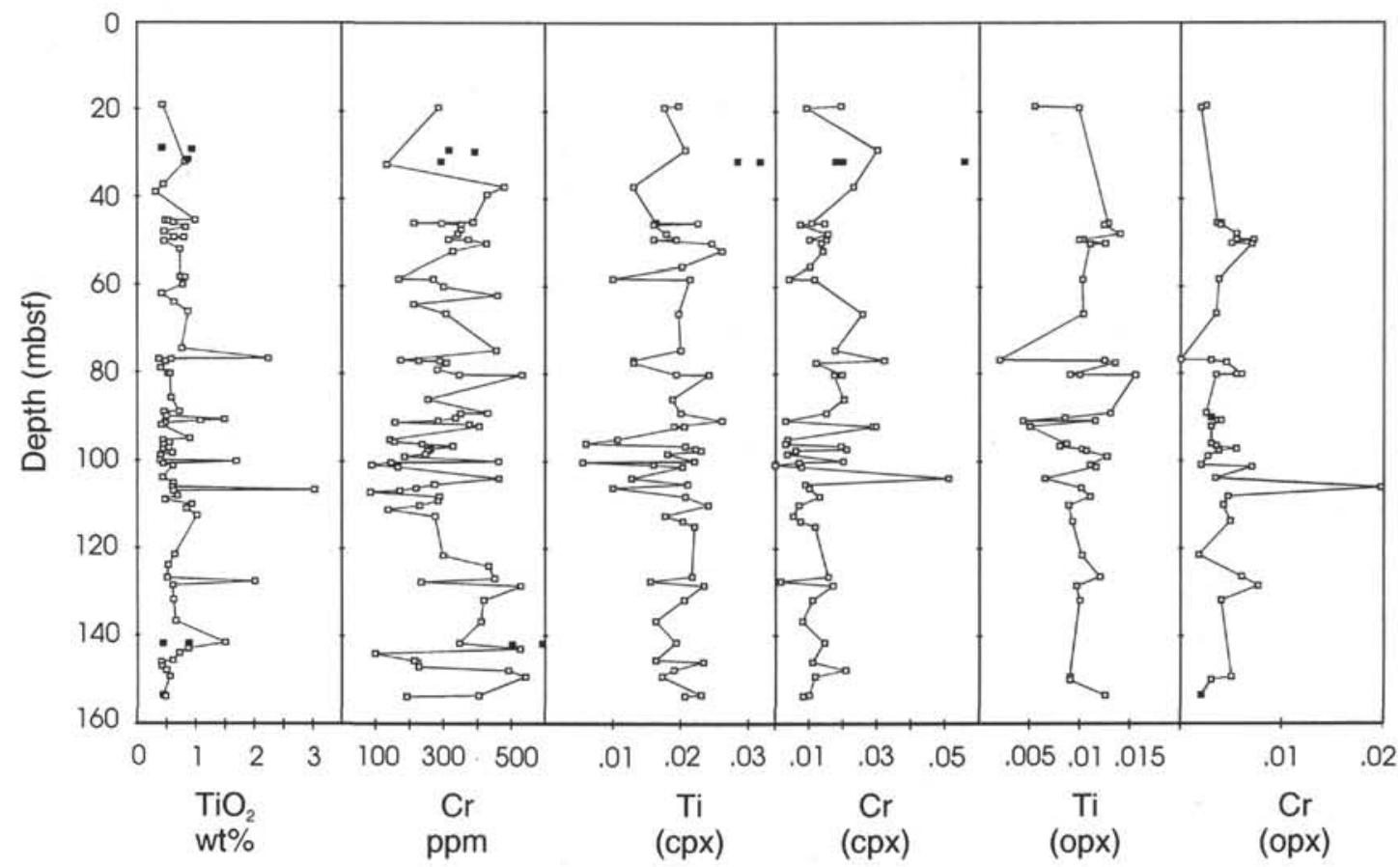

Figure 4. $\mathrm{TiO}_{2}$ and $\mathrm{Cr}$ (bulk rock) content with $\mathrm{Ti}$ and $\mathrm{Cr}$ formula units for orthopyroxene and clinopyroxene plotted against depth in $\mathrm{Hole} 894 \mathrm{G}$. Symbols as in Figure 1.

Mg\#'s. Zr exhibits a general range of nearly 1 order of magnitude from approximately 10 to $100 \mathrm{ppm}$. Sample 147-894G-9R-3 (Piece $5 \mathrm{D}, 80-83 \mathrm{~cm}$ ) is extraordinary enriched with $714 \mathrm{ppm} \mathrm{Zr}$. The REE also exhibit a 1 order of magnitude range (Nd values from approximately 1 to 10 ppm), and Sample 147-894G-9R-3 (Piece 5D, 80-83 $\mathrm{cm})$ is also strongly enriched in these elements (35 ppm Nd).

The loss of ignition (LOI) of the gabbroic rocks varies from 0.1 to $4 \mathrm{wt} \%$. In general, there is no correlation between element abundances and LOI, as demonstrated in Figure 8, where $\mathrm{Zr}$ is plotted vs. LOI.
Potassium represents an exception to this general picture, and there is a clear increase in the abundance of this element with increasing LOI (Fig. 8). This correlation is probably a result of alteration, because unaltered rocks are low in both $\mathrm{H}_{2} \mathrm{O}$ and $\mathrm{K}_{2} \mathrm{O}$.

\section{Basaltic Dikes}

The basaltic dikes show major and trace element abundances similar to those of the gabbroic rocks, and they consequently plot togeth- 


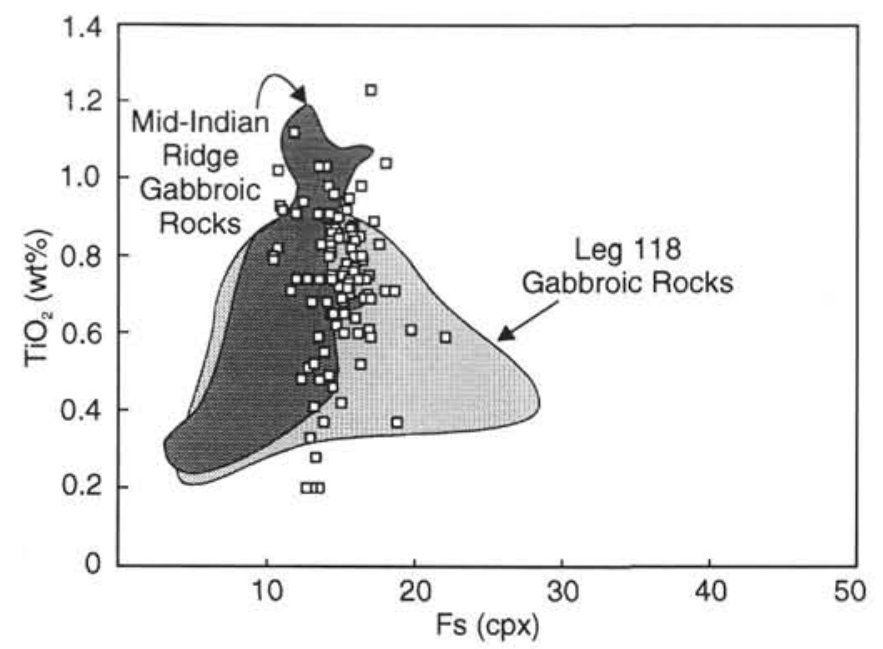

Figure 5. Variation in $\mathrm{TiO}_{2}$ and $\mathrm{Fs}$ content of clinopyroxenes from gabbroic rocks of Hole $894 \mathrm{G}$ compared with Indian Ocean gabbros (fields from Hebert et al., 1991). Symbols as in Figure 1.

er on all the covariation diagrams (Fig. 7). The dikes have slightly lower $\mathrm{SiO}_{2}$ contents than most of the gabbros. This is, however, related to the fact that they are the most hydrated rocks (with LOIs of up to $4 \mathrm{wt} \%)$ and to the closure in geochemical data sets that are expressed as a part of a whole (i.e., percentage and parts per million). The higher LOI of these rocks results, therefore, in lower $\mathrm{SiO}_{2}$ values relative to the less-hydrated gabbros. The basaltic dikes plot within the more primitive end of the spectrum defined by the Site 894 gabbros with regard to $\mathrm{Mg} \#$ 's, $\mathrm{Cr}$, and $\mathrm{Ni}$ (Fig. 7).

\section{REE Compositions}

The gabbroic rocks show a large range in REE abundances (Fig. 9). The range defined by the samples recovered from Site 894 is close to the total range defined by the whole plutonic section of ophiolite complexes (excluding ultramafic cumulates) (Pedersen and Malpas, 1984; R.B. Pedersen, unpub. data). The chondrite-normalized REE patterns of the gabbroic rocks vary from patterns strongly depleted in the light REE (LREE) to slightly LREE-enriched patterns in samples with high total REE abundances. The $\mathrm{Sm} / \mathrm{Nd}$ ratios tend to decrease with a decrease in Mg\#'s, but the trend is poorly defined (Fig. 10). The Eu anomaly of the rocks varies from a positive anomaly in rocks with low total REE abundance to strong negative Eu anomalies in the most enriched rocks. There is no good correlation between the Eu anomaly (expressed as an Eu\#) and Mg\#'s, although there is a tendency for rocks with low Mg\#'s to have low Eu\#'s (Fig. 10).

The basaltic dikes show an REE-depleted trend that is identical to the trend of gabbros with intermediate REE contents (Fig. 9). Some of the basaltic dikes exhibit a moderate positive Eu anomaly, suggesting some plagioclase accumulation.

\section{Downhole Variations in Bulk-rock Compositions}

The downhole variations in the whole-rock compositions of the gabbroic rocks are characterized by dramatic small-scale $(1-5 \mathrm{~m})$ fluctuations in element abundances (Fig. 11). The pattern is particularly pronounced for $\mathrm{Cr}$, which fluctuates between 100 and $500 \mathrm{ppm}$. Most of the spikes on the curve are defined by single samples, and the sampling interval seems, therefore, in general to have been too coarse to define the trend accurately. The closest sampling was carried out between 85 and $105 \mathrm{mbsf}$, and in this interval, some of the spikes are defined by more than one sample (Fig. 12). Between 89 and 92 mbsf, the $\mathrm{Cr}$ content drops from 450 to $150 \mathrm{ppm}$ before it rises to a level at

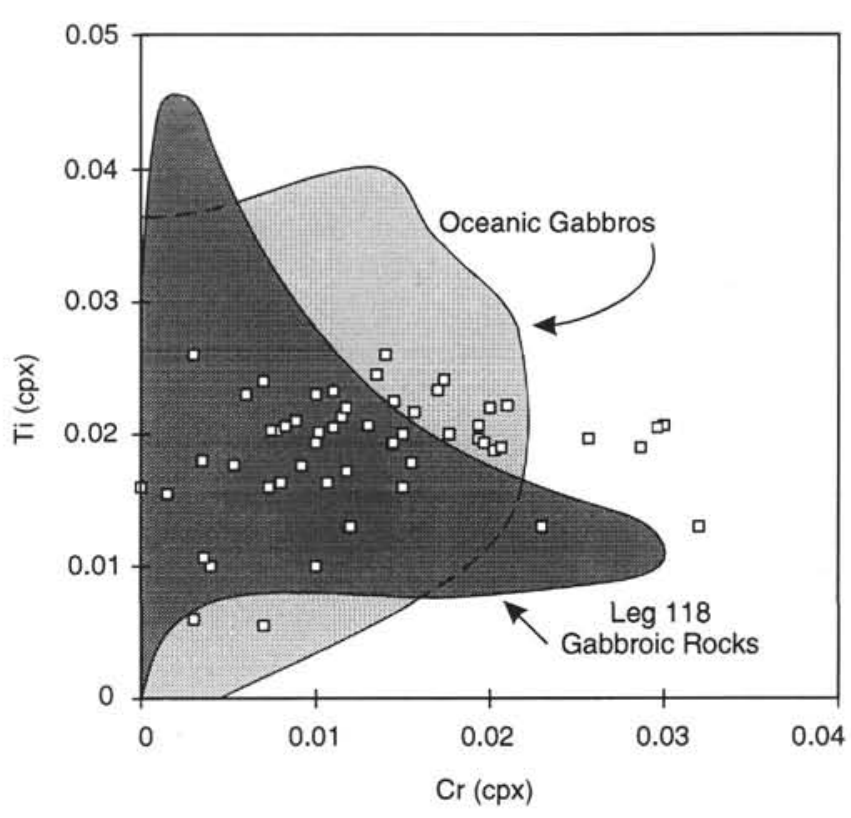

Figure 6. $\mathrm{Ti}$ (formula units) vs. $\mathrm{Cr}$ (formula units) for clinopyroxene from gabbroic rocks of Hole $894 \mathrm{G}$. Symbols as in Figure 1.

about $400 \mathrm{ppm}$. Such meter-scale fluctuations seem to characterize the core. The Mg\#'s also show these sharp variations downhole, although less pronounced than for $\mathrm{Cr}$. Except for some marked spikes, the Ca\#'s vary less than the Mg\#'s. In general, the Ca\#'s and the

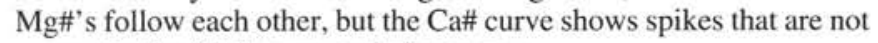
present in the $\mathrm{Mg} \#$ curve and vice versa.

Incompatible trace elements such as $\mathrm{Zr}$ and $\mathrm{Nd}$ show large variations throughout the core (Figs. 11, 12; note the logarithmic scales). The abundances of these elements fluctuate abruptly and show common (but not always) antithetical relations with $\mathrm{Cr}$. At $96.8 \mathrm{mbsf}$, there is a spike where $\mathrm{Cr}, \mathrm{Nd}$, and $\mathrm{Zr}$ increase at the same interval (Fig. 12).

Although the downhole variations are characterized by meterscale fluctuations, there also seems to be some large-scale variations. Between 85 and $100 \mathrm{mbsf}$, there appears to be a small drop in both the general $\mathrm{Cr}$ content as well as the Mg\#'s with increasing depth (Fig. 12). This general decrease with depth is followed by a more pronounced increase with depth between 110 and 140 mbsf (Fig. 11). Therefore, the bulk-rock compositions may fluctuate on several scales downhole. Because pronounced small-scale variations will mask more subtle large-scale variations, a larger data base would be needed to reach a conclusion on this matter.

\section{ISOTOPE GEOCHEMISTRY}

Ten gabbroic and six basaltic dike samples from Site 894 were analyzed for Nd isotope compositions, and the results are listed in Table 2 . The isotopic analyses were carried out at the University of Bergen, and the procedure employed is a modified version of the inverse chromatography methods of Richard et al. (1976). Samples were loaded on a double Rhenium filament and analyzed on a Finnigan 262 thermal mass spectrometer in multicollector mode. ${ }^{143} \mathrm{Nd} / 144 \mathrm{Nd}$ ratios were normalized for mass fractionation using a ${ }^{146} \mathrm{Nd} /{ }^{144} \mathrm{Nd}$ value of 0.7219 . The average ${ }^{143} \mathrm{Nd} /{ }^{144} \mathrm{Nd}$ for the La Jolla standard was $0.51185 \pm 2$, which is the same as the accepted value.

The ${ }^{143} \mathrm{Nd} /{ }^{144} \mathrm{Nd}$ of the gabbroic rocks ranges from 0.513197 to 0.513159 with an average of $0.513188 \pm 13$, and the ${ }^{143} \mathrm{Nd} /{ }^{144} \mathrm{Nd}$ of the basaltic dikes ranges from 0.513201 to 0.513095 with an average of $0.513138 \pm 41$, which are typical mid-oceanic-ridge basalt 
Table 1. Representative bulk-rock analyses of gabbroic and basaltic rocks recovered from Site 894 .

\begin{tabular}{|c|c|c|c|c|c|c|c|c|c|c|c|c|c|}
\hline $\begin{array}{l}\text { Core, section, } \\
\text { interval }(\mathrm{cm})\end{array}$ & Lithology & $\mathrm{SiO}_{2}$ & $\mathrm{TiO}_{2}$ & $\mathrm{Al}_{2} \mathrm{O}_{3}$ & $\mathrm{Fe}_{2} \mathrm{O}_{3}$ & $\mathrm{MnO}$ & $\mathrm{MgO}$ & $\mathrm{CaO}$ & $\mathrm{Na}_{2} \mathrm{O}$ & $\mathrm{K}_{2} \mathrm{O}$ & $\mathrm{P}_{2} \mathrm{O}_{5}$ & LOI & Total \\
\hline \multicolumn{14}{|l|}{ 147-894G- } \\
\hline IR-1, 10-13 & Olivine gabbro & 52.05 & 0.44 & 15.40 & 8.56 & 0.14 & 8.26 & 12.49 & 2.35 & 0.01 & 0.01 & 0.96 & 100.67 \\
\hline $2 \mathrm{R}-2,142-146$ & Olivine gabbro & 51.81 & 0.82 & 14.79 & 10.24 & 0.15 & 7.41 & 10.29 & 2.86 & 0.06 & 0.24 & 1.68 & 100.35 \\
\hline $4 \mathrm{R}-1,20-22$ & Olivine gabbro & 48.59 & 0.99 & 17.07 & 8.86 & 0.14 & 8.59 & 11.77 & 2.24 & 0.00 & 0.05 & 2.55 & 100.85 \\
\hline $6 \mathrm{R}-2,4-9$ & Gabbronorite & 51.21 & 0.74 & 12.60 & 10.77 & 0.18 & 8.77 & 11.59 & 2.43 & 0.03 & 0.12 & 1.61 & 100.05 \\
\hline $6 \mathrm{R}-2,8-11$ & Gabbronorite & 51.84 & 0.82 & 13.53 & 9.68 & 0.17 & 7.98 & 13.30 & 2.36 & 0.00 & 0.02 & 0.28 & 99.98 \\
\hline $9 \mathrm{R}-3,80-83$ & Gabbronorite & 49.78 & 2.23 & 9.88 & 15.89 & 0.20 & 8.50 & 10.08 & 2.49 & 0.01 & 1.01 & 0.92 & 100.99 \\
\hline $11 \mathrm{R}-2,122-129$ & Gabbronorite & 51.48 & 0.50 & 16.03 & 8.40 & 0.14 & 8.28 & 12.48 & 2.01 & 0.01 & 0.01 & 0.58 & 99.92 \\
\hline $11 \mathrm{R}-3,3-7$ & Gabbronorite & 49.20 & 1.49 & 3.70 & 19.76 & 0.29 & 15.03 & 10.68 & 0.86 & 0.00 & 0.09 & 0.00 & 101.10 \\
\hline $13 R-3,125-129$ & Gabbronorite & 50.70 & 1.02 & 12.78 & 12.05 & 0.19 & 9.53 & 11.83 & 1.77 & 0.00 & 0.04 & 0.00 & 99.91 \\
\hline $20 \mathrm{R}-3,112-118$ & Gabbronorite & 51.54 & 0.48 & 16.26 & 8.69 & 0.14 & 8.71 & 11.97 & 2.02 & 0.01 & 0.03 & 0.26 & 100.11 \\
\hline $2 \mathrm{R}-1,11-14$ & Basaltic dike & 50.31 & 0.44 & 17.23 & 8.61 & 0.13 & 8.22 & 12.42 & 2.25 & 0.04 & 0.04 & 1.15 & 100.84 \\
\hline $2 \mathrm{R}-1,60-65$ & Basaltic dike & 48.23 & 0.94 & 17.43 & 8.33 & 0.14 & 9.14 & 11.72 & 1.95 & 0.00 & 0.06 & 2.01 & 99.95 \\
\hline $2 \mathrm{R}-2,95-100$ & Basaltic dike & 47.62 & 0.87 & 18.16 & 7.90 & 0.14 & 8.68 & 11.96 & 1.84 & 0.00 & 0.07 & 2.35 & 99.59 \\
\hline $19 \mathrm{R}-1,49-55$ & Basaltic dike & 46.34 & 0.88 & 18.97 & 7.91 & 0.12 & 8.84 & 10.46 & 2.03 & 0.04 & 0.07 & 4.28 & 99.94 \\
\hline \multirow{3}{*}{$\begin{array}{l}147-894 \mathrm{~F}- \\
3 \mathrm{R}-1,123-128\end{array}$} & & & & & & & & & & & & & \\
\hline & Basaltic dike & 48.02 & 1.00 & 17.22 & 9.27 & 0.15 & 8.47 & 11.01 & 2.37 & 0.02 & 0.07 & 2.90 & 100.50 \\
\hline & & $\mathrm{V}$ & $\mathrm{Cr}$ & Co & $\mathrm{Ni}$ & $\mathrm{Cu}$ & $\mathrm{Zn}$ & $\mathrm{Rb}$ & $\mathrm{Sr}$ & $\mathrm{Y}$ & $\mathrm{Zr}$ & $\mathrm{Nb}$ & \\
\hline $\begin{array}{l}147-894 \mathrm{G}- \\
1 \mathrm{R}-1,10-13\end{array}$ & Olivine gabbro & 200 & 285 & 45 & 104 & 80 & 59 & I & 97 & 16 & 19 & 0 & \\
\hline $2 \mathrm{R}-2,142-146$ & Olivine gabbro & 266 & 132 & 44 & 75 & $\begin{array}{l}80 \\
47\end{array}$ & 64 & i & 99 & 46 & $\begin{array}{l}17 \\
86\end{array}$ & 4 & \\
\hline $4 \mathrm{R}-1,20-22$ & Olivine gabbro & 216 & 386 & 45 & 196 & 83 & 71 & i & 87 & 27 & 52 & 0 & \\
\hline $6 \mathrm{R}-2,4-9$ & Gabbronorite & 263 & 167 & 50 & 86 & 64 & 82 & 0 & 81 & 42 & 63 & 2 & \\
\hline $6 \mathrm{R}-2,8-11$ & Gabbronorite & 283 & 269 & 48 & 79 & 131 & 67 & 3 & 90 & 26 & 33 & 1 & \\
\hline $9 \mathrm{R}-3,80-83$ & Gabbronorite & 356 & 172 & 53 & 83 & 8 & 52 & 0 & 78 & 106 & 714 & 12 & \\
\hline $11 \mathrm{R}-2,122-129$ & Gabbronorite & 209 & 334 & 43 & 88 & 81 & 57 & 1 & 101 & 14 & 20 & 0 & \\
\hline $11 \mathrm{R}-3,3-7$ & Gabbronorite & 349 & 282 & 67 & 144 & 65 & 120 & 2 & 23 & 49 & 90 & 5 & \\
\hline $13 R-3,125-129$ & Gabbronorite & 443 & 274 & 53 & 93 & 77 & 77 & 0 & 79 & 24 & 29 & 2 & \\
\hline $20 \mathrm{R}-3,112-118$ & Gabbronorite & 228 & 190 & 43 & 103 & 85 & 56 & 1 & 92 & 14 & 24 & 1 & \\
\hline $2 \mathrm{R}-1,11-14$ & Basaltic dike & 153 & 317 & 47 & 145 & 99 & 64 & 0 & 117 & 14 & 26 & 0 & \\
\hline $2 \mathrm{R}-1,60-65$ & Basaltic dike & 231 & 392 & 43 & 218 & 90 & 59 & 1 & 92 & 25 & 51 & 2 & \\
\hline $2 \mathrm{R}-2,95-100$ & Basaltic dike & 231 & 295 & 43 & 206 & 89 & 60 & i & 92 & 23 & 48 & 1 & \\
\hline $19 \mathrm{R}-1,49-55$ & Basaltic dike & 251 & 594 & 43 & 378 & 85 & 66 & 2 & 100 & 27 & 53 & 1 & \\
\hline \multicolumn{14}{|l|}{$147-894 \mathrm{~F}-$} \\
\hline $3 R-1,123-128$ & Basaltic dike & 222 & 396 & 47 & 211 & 94 & 75 & 2 & 91 & 29 & 58 & 2 & \\
\hline & & $\mathrm{La}$ & $\mathrm{Ce}$ & $\operatorname{Pr}$ & $\mathrm{Nd}$ & Sm & Eu & Gd & $\mathrm{Tb}$ & Dy & Ho & $\mathrm{Er}$ & $\mathrm{Lu}$ \\
\hline \multicolumn{14}{|l|}{ 147-894G- } \\
\hline IR-1, 10-13 & Olivine gabbro & 0.64 & 1.70 & 0.34 & 2.12 & 1.11 & 0.54 & 1.32 & 0.25 & 1.91 & 0.39 & 1.36 & 0.18 \\
\hline $2 R-2,142-146$ & Olivine gabbro & 4.40 & 12.85 & 2.19 & 10.58 & 4.05 & 1.17 & 5.36 & 0.87 & 5.70 & 1.14 & 3.68 & 0.50 \\
\hline $4 \mathrm{R}-1,20-22$ & Olivine gabbro & 1.26 & 4.27 & 0.81 & 4.54 & 2.06 & 0.74 & 2.64 & 0.51 & 3.22 & 0.65 & 2.15 & 0.27 \\
\hline $6 \mathrm{R}-2,4-9$ & Gabbronorite & 3.02 & 9.40 & 1.61 & 8.82 & 3.41 & 1.04 & 4.96 & 0.84 & 5.68 & 1.15 & 3.64 & 0.55 \\
\hline $6 \mathrm{R}-2,8-11$ & Gabbronorite & 1.24 & 4.03 & 0.80 & 4.15 & 1.88 & 0.91 & 2.77 & 0.48 & 3.56 & 0.74 & 2.55 & 0.33 \\
\hline $9 \mathrm{R}-3,80-83$ & Gabbronorite & 15.86 & 45.78 & 7.30 & 35.41 & 11.06 & 2.09 & 14.81 & 2.35 & 15.00 & 3.19 & 9.04 & 1.23 \\
\hline $11 \mathrm{R}-2,122-129$ & Gabbronorite & 0.55 & 1.64 & 0.32 & 1.90 & 0.98 & 0.49 & 1.49 & 0.25 & 1.75 & 0.39 & 1.22 & 0.15 \\
\hline $11 \mathrm{R}-3,3-7$ & Gabbronorite & 3.02 & 9.54 & 1.69 & 9.09 & 3.74 & 0.70 & 5.34 & 0.92 & 6.30 & 1.37 & 4.05 & 0.61 \\
\hline $13 \mathrm{R}-3,125-129$ & Gabbronorite & 0.89 & 3.03 & 0.56 & 3.81 & 1.90 & 0.67 & 2.51 & 0.47 & 3.50 & 0.71 & 2.16 & 0.31 \\
\hline $20 \mathrm{R}-3,112-118$ & Gabbronorite & 0.70 & 2.06 & 0.34 & 2.11 & 1.07 & 0.46 & 1.32 & 0.25 & 1.75 & 0.35 & 1.21 & 0.14 \\
\hline $2 \mathrm{R}-1,11-14$ & Basaltic dike & 0.92 & 2.56 & 0.43 & 2.23 & 0.93 & 0.54 & 1.37 & 0.25 & 1.80 & 0.37 & 1.22 & 0.14 \\
\hline $2 \mathrm{R}-1,60-65$ & Basaltic dike & 1.43 & 4.31 & 0.91 & 4.75 & 2.06 & 0.90 & 2.98 & 0.56 & 3.75 & 0.78 & 2.43 & 0.34 \\
\hline $2 \mathrm{R}-2,95-100$ & Basaltic dike & 1.16 & 3.82 & 0.77 & 4.19 & 1.72 & 0.72 & 2.71 & 0.50 & 3.29 & 0.74 & 1.97 & 0.29 \\
\hline $19 \mathrm{R}-1,49-55$ & Basaltic dike & 1.23 & 4.02 & 0.78 & 4.36 & 1.80 & 0.88 & 2.77 & 0.50 & 3.34 & 0.69 & 2.04 & 0.31 \\
\hline \multicolumn{14}{|l|}{$147-894 \mathrm{~F}-$} \\
\hline $3 R-1,123-128$ & Basaltic dike & 1.45 & 4.68 & 0.92 & 5.08 & 2.24 & 0.94 & 2.96 & 0.52 & 3.58 & 0.78 & 2.27 & 0.28 \\
\hline
\end{tabular}

(MORB) values. The results show that there are no apparent variations in the ${ }^{143} \mathrm{Nd} / 144 \mathrm{Nd}$ isotope ratio of the gabbroic rocks with depth, and that within statistical uncertainties, there are no apparent differences between the $\mathrm{Nd}$ isotope signatures of the gabbroic and the basaltic rocks.

The Nd isotope signatures of the Site 894 rocks are comparable to those of gabbroic rocks associated with the upper mantle lithologies that were recovered from Site 895 . A basaltic dike that crosscut the Site 895 rocks shows, however, a Nd isotope signature that is significantly less radiogenic than the signature of the Site 894 rocks (see Allan et al., this volume).

\section{DISCUSSION}

\section{Cumulate vs. Liquid Composition of the Gabbroic Rocks}

Considering the relatively small fraction of the total crust that was sampled in Site 894 and the uniform appearance of most of the samples, the analyzed rocks show a surprisingly large variation in incom- patible trace elements. The REE patterns of the Site 894 rocks vary from those of a typical cumulate gabbro, with a positive Eu anomaly, to the pattern of a highly evolved plagiogranite with a strong negative Eu anomaly. The range these gabbroic rocks exhibit is comparable to the total range observed in plutonic sections of ophiolite complexes (excluding the ultramafic portion). Gabbroic rocks that do not exhibit any Eu anomalies show similar REE compositions to the crosscutting dikes. There is also a striking similarity in major and other trace element compositions, as well as in the isotope signatures of these rocks. The average compositions of the gabbroic and basaltic rocks are also similar. The only significant differences in the averages of the gabbros and the basaltic dikes is a slightly higher $\mathrm{Mg \#}$ and somewhat higher $\mathrm{Cr}$ and $\mathrm{Ni}$ contents for the dikes. MORB-normalized trace element patterns of the two averages, as well as the total ranges exhibited by the gabbroic and basaltic rocks are shown in Figure 13. The close comparison between the two trace element patterns is striking, and the patterns are quite distinct from normal MORB, which is much less depleted in incompatible trace elements. The presence of similar and unusual trace element signatures strongly suggests that 

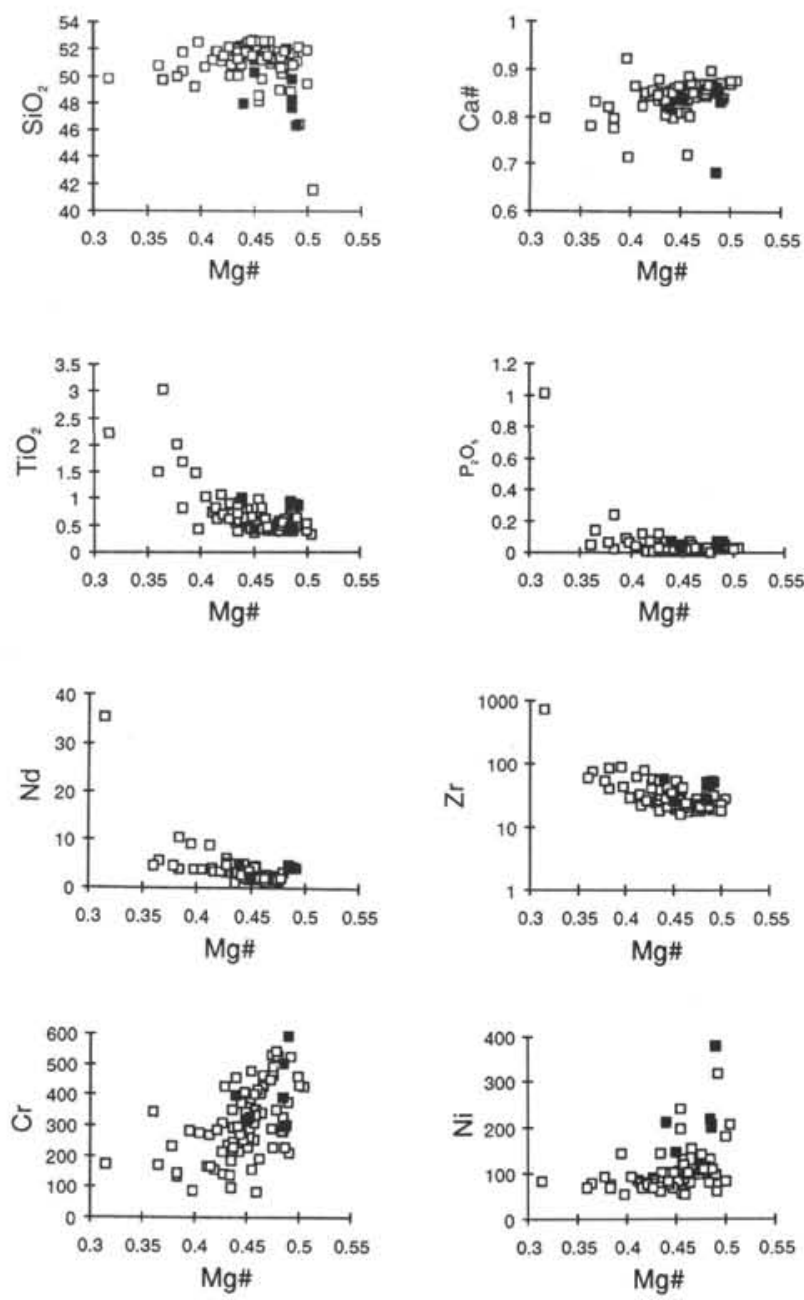

Figure 7. Variation in $\mathrm{SiO}_{2}, \mathrm{Ca}$, $\mathrm{TiO}_{2}, \mathrm{P}_{2} \mathrm{O}_{5}, \mathrm{Nd}, \mathrm{Zr}, \mathrm{Cr}$, and $\mathrm{Ni}$ vs. $\mathrm{Mg \#}$ of gabbroic and basaltic rocks from Hole 894G. Symbols as in Figure 1.

the gabbroic rocks and the basaltic dikes are petrogenetically related to each other.

The depleted nature of the parental magma of the gabbroic rocks can also be demonstrated using covariations in Nd and Eu\#'s of the rocks. Incompatible elements like Nd increase exponentially with decreasing Eu\#'s in the Site 894 gabbros (Fig. 14). This is to be expected because high Eu\#'s suggest a high cumulate affinity, which also should imply a low content of incompatible trace elements and vice versa. The observed trend can be modeled using a Rayleigh fractionation equation and reasonable partition coefficients (Fig. 14). Because the Eu\# of the primary magma (the magma extracted from the mantle) can be assumed to be zero (independent of whether the magma is depleted or enriched), this diagram demonstrates that the parental magma to the Site 894 gabbros would have to be highly depleted (with Nd values about 4-5 ppm, which are similar to the basaltic dikes from Site 894). A parental magma with $\mathrm{Nd}$ contents similar to undepleted East Pacific Rise basalt (10-20 ppm Nd; Hekinian et al., 1989) would plot on the observed trend only if it had an Eu\# of about -0.5 , (i.e., similar to oceanic plagiogranite).

We conclude, therefore, that the average composition of the gabbros is close to a liquid composition, and that the dikes and the gabbros are related to each other. The basaltic dikes are strongly depleted and the gabbro compositions also suggest a highly depleted parental magma. This is consistent with geochemical data from Site 895, which indicate that the harzburgites are very refractory (Dick et al.,
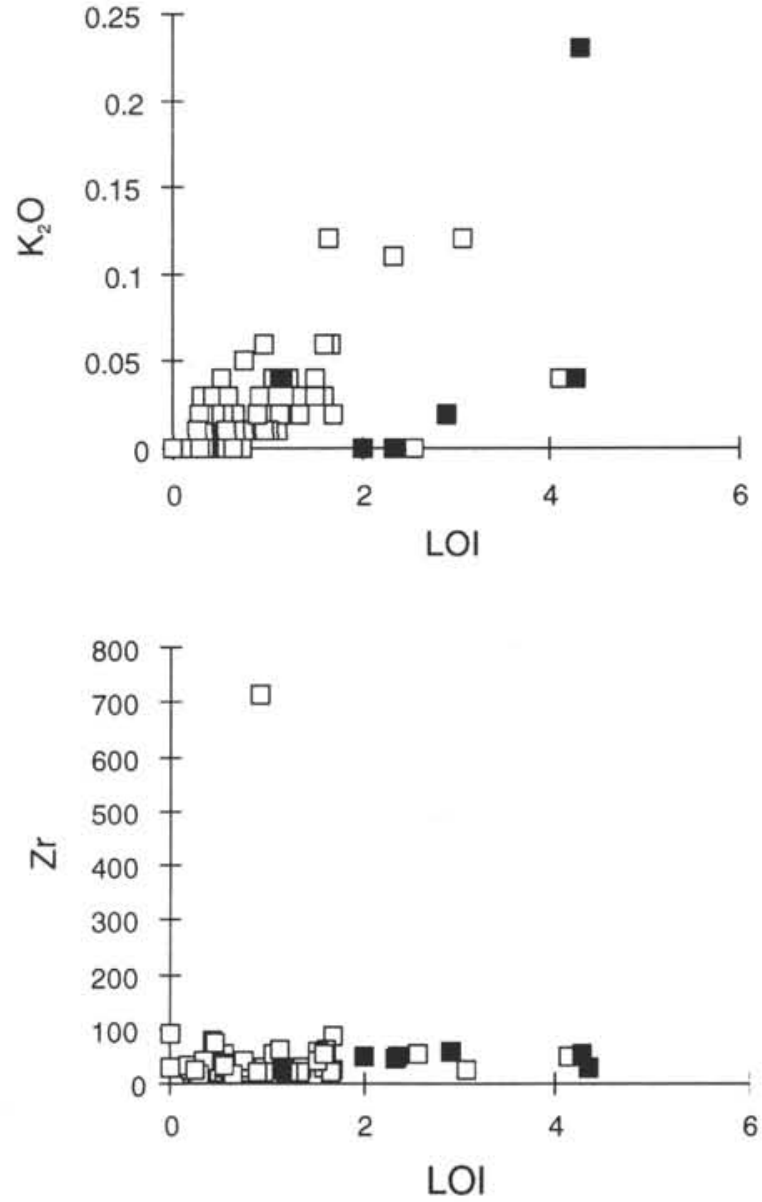

Figure 8. Variation of $\mathrm{K}_{2} \mathrm{O}$ and $\mathrm{Zr}$ vs. loss on ignition (LOI) for gabbroic and basaltic rocks. Symbols as in Figure 1.

this volume). Depleted lavas are reported from crust formed along the Cocos-Nazca ridge (Autio and Rhodes, 1983; Autio et al., 1989) as well as from the East Pacific Rise (Hekinian et al., 1989). Along both ridges, the depleted basalts are closely related both in time and space with normal and transitional MORB.

\section{Decoupling in Trace Element Behavior}

Although the average composition of the gabbroic rocks is similar to that of the basaltic dikes that intrude them, the gabbroic rocks have a much wider compositional range, particularly in the incompatible element abundances. There are several aspects of this variability that seem not to follow the pattern of observed or modeled differentiation trends. The most enriched rocks have both REE patterns and abundances similar to the plagiogranites present in some ophiolite complexes. The gabbroic rocks show, however, no $\mathrm{SiO}_{2}$ enrichments, and there is no quartz present in any of the rocks. Another unusual feature is the fact that $\mathrm{Cr}$ contents show a poor trend when plotted against Mg\#'s, but a well-defined trend when plotted against Ca\#'s (Fig. 15), whereas the opposite is the case for elements such as $\mathrm{TiO}_{2}$ and $\mathrm{Zr}$ (they show good trends against Mg\#'s and no trend against Ca\#'s, Fig. 15). Thus, there appears to be a decoupling in the behavior of incompatible and compatible trace elements in the gabbros.

Cumulate minerals of plutonic rocks may not always be present in cotectic proportions, and the trace element abundances of such rocks may therefore reflect modal variations rather than the evolution of the parental liquid. We have as yet no modal point-counting data, but normative data show that clinopyroxene and plagioclase range in 
A

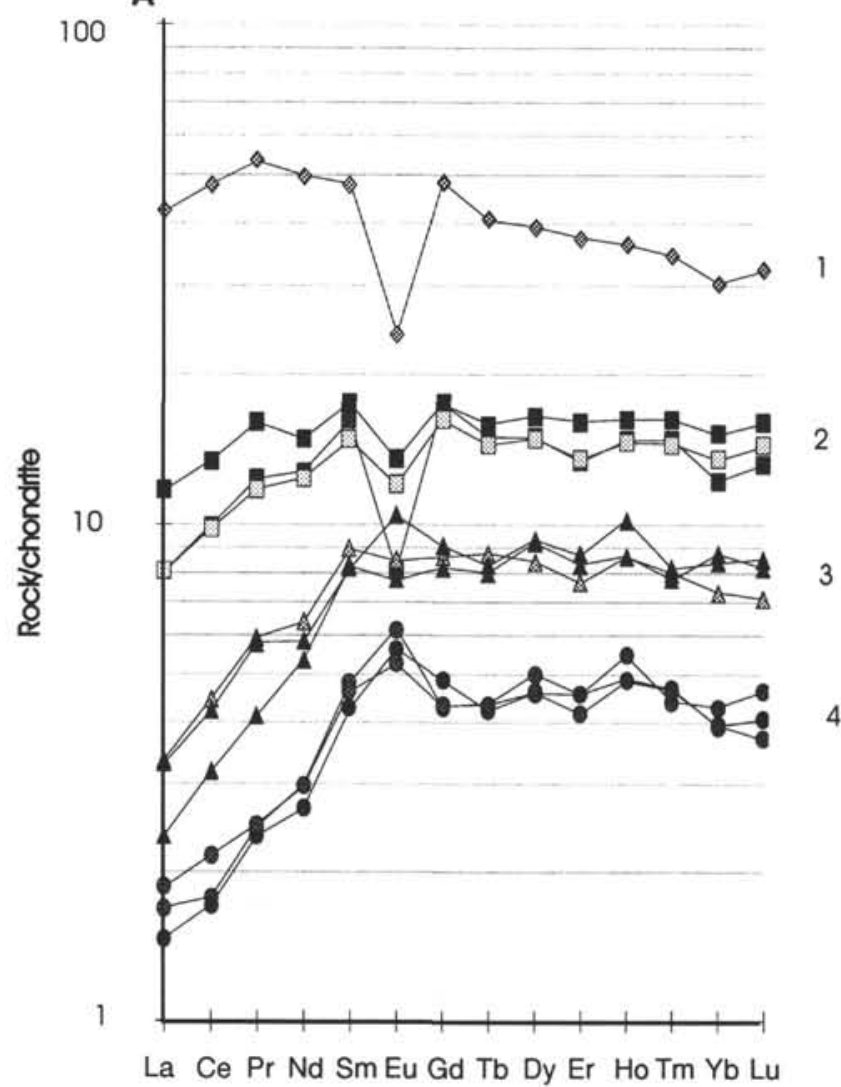

B

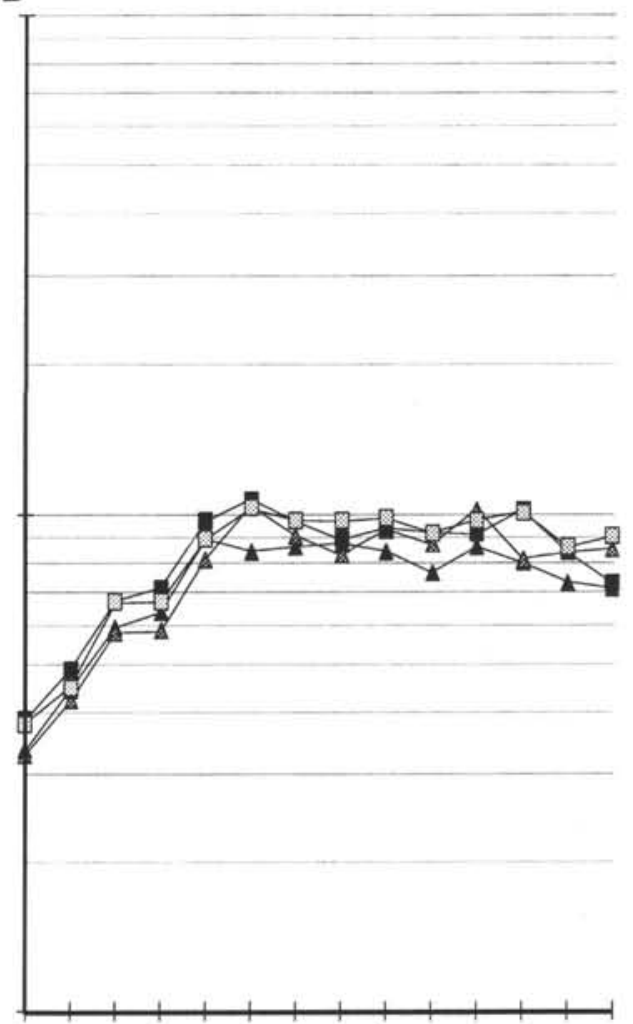

La Ce Pr Nd Sm Eu Gd Tb Dy Er Ho Tm Yb Lu

Figure 9. A. Chondrite-normalized REE patterns of representative gabbroic rocks from Hole 894G. B. Chondrite-normalized REE patterns of basaltic dikes from Hole 894G compared with gabbroic rocks exhibiting no Eu anomaly. Symbols as in Figure 1.

abundance from $10 \%$ to $37 \%$ and from $41 \%$ to $68 \%$, respectively. Because $\mathrm{Cr}$ partitions strongly into clinopyroxene, one could expect to see a correlation between this element and the amount of normative clinopyroxene (assuming that the normative data reflect the modal abundance of the mineral in the rocks). There is, however, no such correlation (Fig. 16). The $\mathrm{Cr}$ content of the whole rock seems rather to be controlled by the composition of the clinopyroxenes. The clinopyroxenes vary considerably in $\mathrm{Cr}$, and variations in the $\mathrm{Cr}$ content of the whole rock follow the variations in the $\mathrm{Cr}$ content of the clinopyroxenes downhole (Fig. 4). This suggests that the effect of varying modal abundances has only a subordinate effect on the $\mathrm{Cr}$ content of the whole rock.

The mineral analyses show that there is a much more restricted range in Mg\#'s of clinopyroxenes than there is in the whole-rock

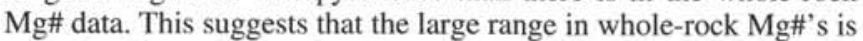
not related to variations in silicate mineral compositions, but is due to varying modal amounts of oxides in the rocks. It is therefore reasonable that $\mathrm{Cr}$, which partitions strongly into clinopyroxene, shows a dispersed trend when plotted against whole-rock Mg\#'s, as variations in this index are controlled by the modal abundance of oxides. It is also reasonable that the trend on the $\mathrm{Cr}$ vs. Ca\# diagram (Fig. 15) is more well defined, as the composition of the silicate phases under such conditions are best reflected by this fractionation index. The fact that $\mathrm{TiO}_{2}$ and the incompatible trace elements show a reverse relation (i.e., with well-defined trends when plotted against Mg\#'s and no trend at all when plotted against Ca\#'s), provides essential information on the petrogenesis of these rocks.

The lack of any correlation between $\mathrm{TiO}_{2}$ and $\mathrm{Zr}$ with Ca\#'s (Fig. 15) suggests that the abundance of oxides and incompatible element- bearing phases such as zircon and apatite (which was observed) is unrelated to the composition of the silicate matrix. The decoupling of compatible and incompatible elements may thus be explained by the fact that compatible elements are controlled by the composition of the silicate matrix whereas the incompatible elements and $\mathrm{TiO}_{2}$ are not. This evidence suggests that the geochemistry of the Site 894 gabbros is not controlled by mineral crystallization and fractionation alone.

The apparent decoupling between incompatible and compatible elements is further substantiated in Figure 14, where $\mathrm{Cr}$ and $\mathrm{Nd}$ are plotted against Eu\#'s. Nd shows an exponential enrichment trend with decreasing Eu\#'s, and this trend can be perfectly modeled by fractional crystallization using reasonable partition coefficients. $\mathrm{Cr}$ also defines a trend when plotted against Eu\#'s, but this trend cannot be modeled either as a liquid line of descent trend or as a cumulate line of descent (Fig. 14).

\section{Fractional Crystallization, Trapping, and Migration of Interstitial Melts}

The anomalous behavior of the trace elements may have several explanations. Mixing relations combined with the compositional effects of fractional or equilibrium crystallization seem to explain the observed decoupling. In a magma undergoing crystallization, a series of different mixing relations can be pictured:

1. Magma mixing (i.e., the mixing of two liquids).

2. Crystal-liquid mixing, which is the mixing between a crystalline matrix and a liquid. Two contrasting cases of such mixing may be envisioned: (a) equilibrium crystal-liquid mixing (i.e., 
mixing between a crystalline matrix made up of unzoned crystals and the liquid in equilibrium with the crystals) and (b) disequilibrium crystal-liquid mixing, which would be the mixing between crystals and a liquid that was not in equilibrium with the entire crystalline matrix. Examples would be trapping of intercumulus liquid in a matrix of zoned crystals or trapping of liquid that infiltrated a matrix that crystallized from a more primitive liquid or vice versa. (Trapping of intercumulus liquid would in general be a disequilibrium crystal-liquid mixing.)

3. Combinations of magma mixing and crystal-liquid mixing (for instance, if magma mixing takes place within the crystalline matrix).

The effects of such mixing relations have been considered in Figure 17 , where the $\mathrm{Cr} / \mathrm{Nd}$ ratio is plotted against Eu\#'s. Mixing lines for magma-mixing, equilibrium crystal-liquid mixing, and disequilibrium crystal-liquid mixing are shown on the same diagram, together with liquid and cumulate lines of descent. The gabbroic rocks plot along a broad trend that clearly show a more gentle decrease in the $\mathrm{Cr} / \mathrm{Nd}$ ratio with decreasing Eu\#'s than one would expect if the trend was caused by fractional crystallization alone. Rocks with positive Eu\#'s (i.e., positive Eu anomalies) plot between the liquid and the cumulate lines of descent and are generally parallel with the computed equilibrium crystal-liquid mixing lines. This suggests that the covariation among $\mathrm{Cr}, \mathrm{Nd}$, and Eu\#'s seen in the rocks may be explained as a combination of fractional crystallization and trapping of intercumulus liquids (i.e., any variations along the $\mathrm{F}$ vector in Figure 17 are due to fractional crystallization, whereas different amounts of trapped interstitial liquid will give rise to variations along the $\mathrm{M}$ vector).

A decoupling in the behavior of $\mathrm{Cr}$ and $\mathrm{Nd}$ is particularly clear for samples that have a negative Eu\# (i.e., negative Eu anomaly). If the covariation of $\mathrm{Nd}$ and $\mathrm{Cr}$ were controlled by fractional crystallization and varying cumulate affinity (i.e., varying amounts of trapped liquid) alone, one would not expect any data points in this area because such rocks will have high incompatible element concentrations and pronounced Eu anomalies but also high $\mathrm{Cr}$ contents. The most incompatible-element-enriched rocks show Eu\#'s at about -0.5 although their $\mathrm{Cr} / \mathrm{Nd}$ ratios are in the 5 to 50 range, which is $1-2$ orders of magnitude higher than one would expect if the compositions were controlled by fractional crystallization alone. This apparent incongruity is probably not an artifact of unrealistic modeling parameters because plagiogranites (which are assumed to have formed by fractional crystallization of MORB) that exhibit similar high REE abundances and Eu\#'s show $\mathrm{Cr} / \mathrm{Nd}$ ratios compatible with the values expected from the trace element modeling (i.e., 2 to 3 orders of magnitude lower than that exhibited by the Site 894 gabbros).

The modeling demonstrates that mixtures of highly evolved and incompatible-element-rich magmas with $\mathrm{Cr}$-rich parental magmas (or, alternatively, disequilibrium mixing of evolved liquid with a more "primitive" crystalline matrix) may yield covariation between compatible and incompatible elements similar to that seen in the trace-element-enriched gabbros. Because the incompatible-elementenriched rocks are present only as small pods and pockets, it seems unlikely that they should be the product of magma mixing prior to crystallization. Disequilibrium crystal-liquid mixing would therefore seem to be a more likely process. Thus, it seems clear that the total variability between compatible and incompatible trace elements observed in the gabbroic rocks may be well explained by a model involving equilibrium and disequilibrium crystal-liquid mixing combined with fractional crystallization.

The liquids that enriched the gabbros in incompatible trace elements must have been highly evolved, and the lack of any quartz and sodium-rich plagioclase in the rocks seems, therefore, difficult to explain with the above model alone.

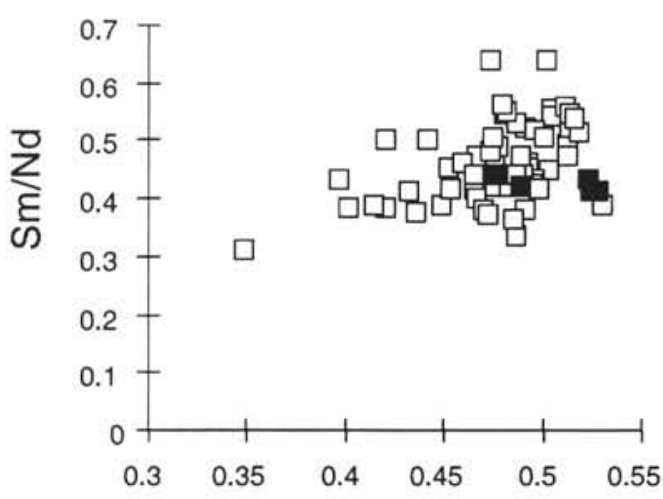

$\mathrm{Mg} \#$

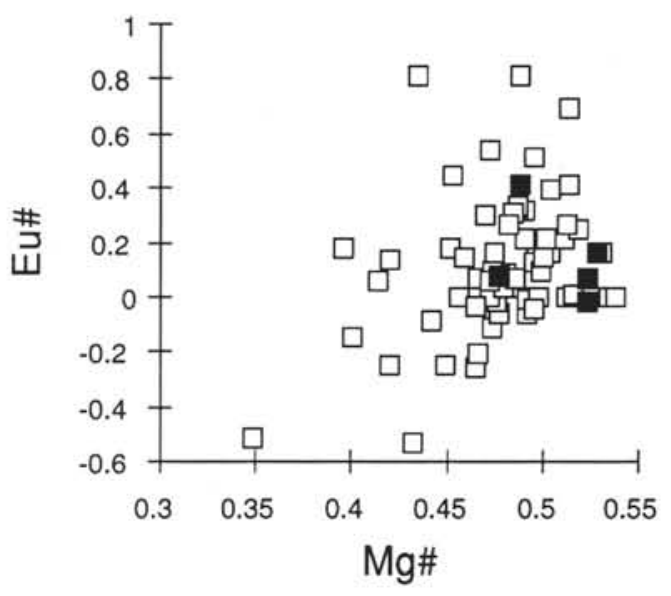

Figure 10. Variation in $\mathrm{Sm} / \mathrm{Nd}$ ratio and Eu\# of gabbroic and basaltic rocks from Hole $894 \mathrm{G}$. Symbols as in Figure 1.

This feature could possibly be explained by thermal migration (see Buchwald et al., 1985). An experimental crystallization study of MORB in a thermal gradient demonstrated that compositional gradients developed rapidly and that elements such as $\mathrm{P}, \mathrm{Ti}$, and Fe became enriched toward the cold end and $\mathrm{Si}, \mathrm{Al}$, and $\mathrm{Na}$ became enriched toward the hot end of the charges, while elements such as $\mathrm{Ca}$ and $\mathrm{Mg}$ were not affected to any significant extent by the process (Lesher and Walker, 1988). This alternative model could explain the presence of interstitial growth of apatite in otherwise primitive rocks, without the simultaneous crystallization of interstitial quartz and sodic plagioclase. Elements such as $\mathrm{P}, \mathrm{Ti}$, and $\mathrm{Fe}$ would be enriched in the pore liquid at the cold end, where the elements rapidly would become trapped, while silica and sodium would be transported toward the interior of the magma chamber and away from the crystallizing front.

\section{Deuteric Enrichment}

The strong enrichment of incompatible elements as seen in some of the rocks could be deuteric in origin (i.e., formed by the infiltration of a late magmatic volatile-rich phase. This mechanism would essentially be the same as that suggested above except that the enriching and infiltrating phase would be highly enriched in volatiles. However, the lack of any covariation between incompatible trace elements and loss on ignition gives us no ground to imply the involvement of 


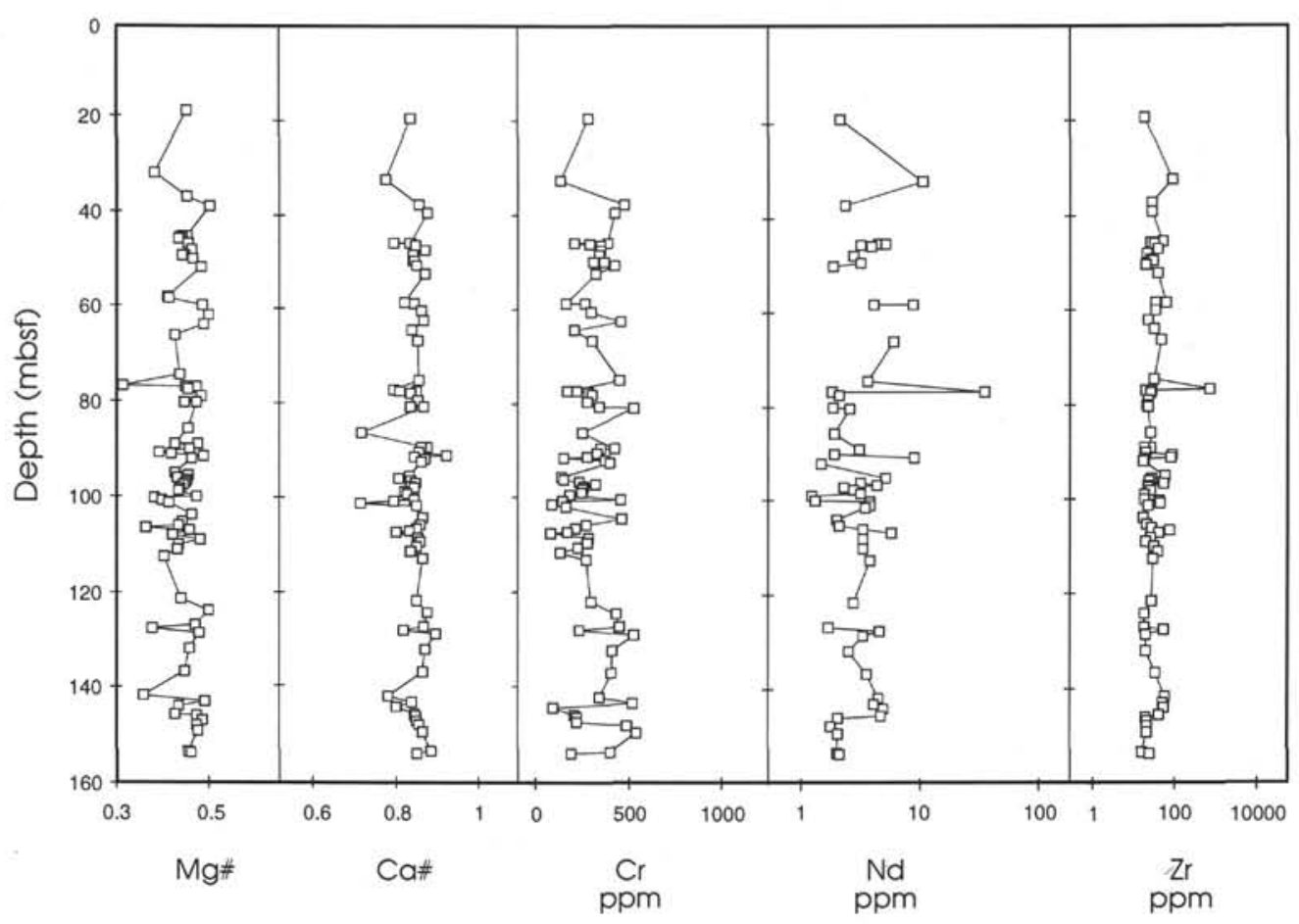

Figure 11. Variation in Mg\#, Ca\#, Cr, Nd, and Zr with depth in Hole 894G. Symbols as in Figure 1.

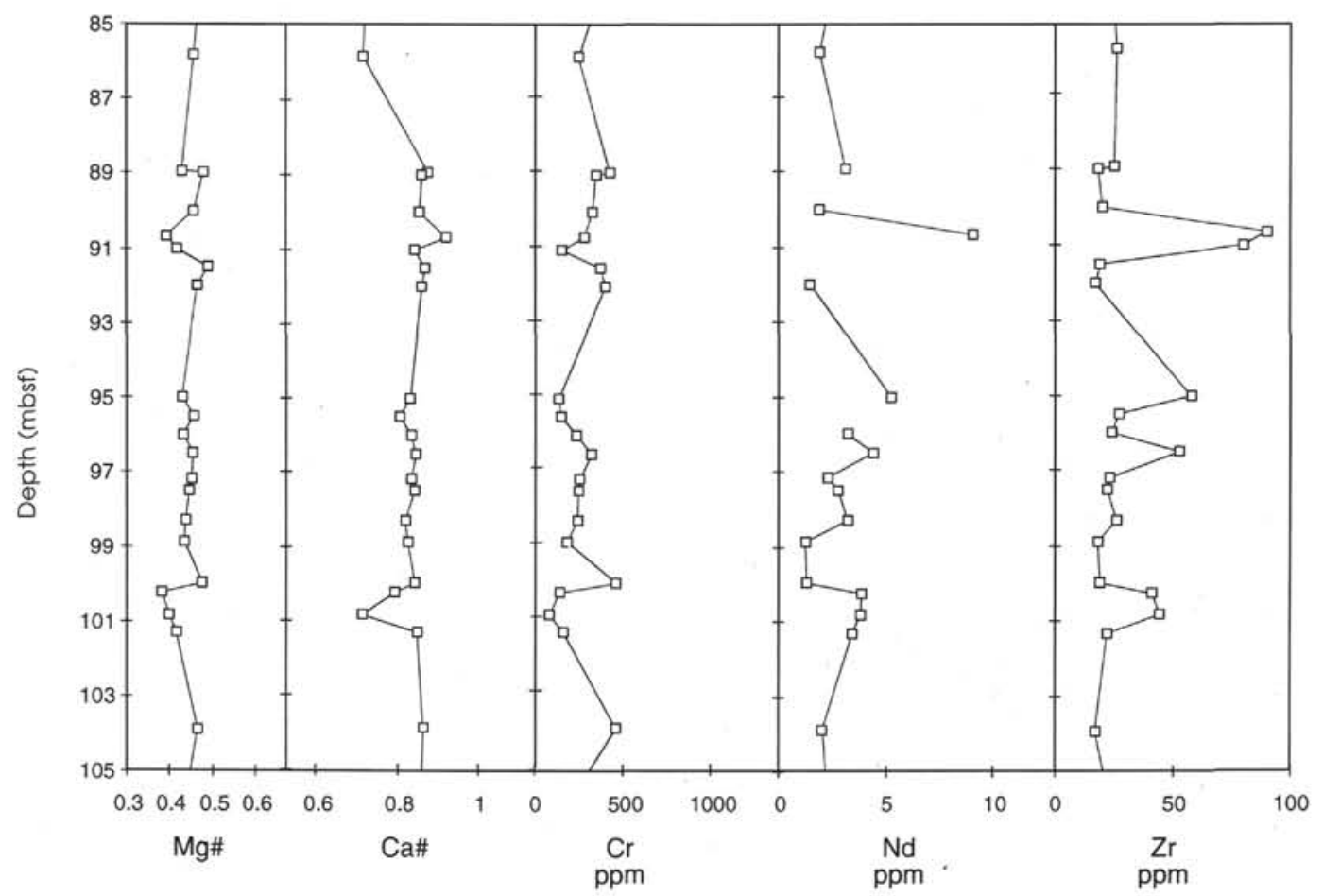

Figure 12. Variation in Mg\#, Ca\#, Cr, Nd, and $\mathrm{Zr}$ with depth in the interval between 85 and 105 mbsf in Hole 894G. Symbols as in Figure 1.

a very volatile-rich late magmatic fluid on our data set alone. Such a correlation can not be discounted as it may have existed and been masked by subsequent lower temperature metamorphic events.

\section{Degree of Cumulate Affinity}

Estimating the degree of cumulate affinity or the amount of trapped liquid is not trivial and the results may easily become mis- leading. First, a parental magma composition has to be assumed and the degree of fractionation must be estimated (see Natland et al., 1991, and references therein). Such a calculation also assumes that there is no percolation of pore fluids through the crystallizing matrix, which, as this study indicates, may not always be true. The results obtained are highly sensitive to the composition of the parental magma used for the calculations. If one of the basaltic dikes recovered from 
Table 2. Nd-isotope compositions for representative gabbroic and basaltic dikes recovered from Site 894 .

\begin{tabular}{cll}
\hline $\begin{array}{c}\text { Core, section, } \\
\text { interval }(\mathrm{cm})\end{array}$ & Lithology & ${ }^{143} \mathrm{Nd} /{ }^{144} \mathrm{Nd}$ \\
\hline $147-894 \mathrm{G}-$ & & \\
4R-1, 20-22 & Olivine gabbro & $0.513159 \pm 6$ \\
6R-2, -11 & Gabbronorite & $0.513197 \pm 7$ \\
11R-2, 122-129 & Gabbronorite & $0.513197 \pm 4$ \\
12R-4, 22-29 & Gabbronorite & $0.513183 \pm 5$ \\
13R-3, 125-129 & Gabbronorite & $0.513194 \pm 5$ \\
20R-1, 1-4 & Gabbronorite & $0.513193 \pm 9$ \\
20R-3, 112-118 & Gabbronorite & $0.513194 \pm 6$ \\
Average of gabbros & & $0.513188 \pm 13$ \\
$147-894 \mathrm{G}-$ & & \\
2R-1, 11-14 & Basaltic dike & $0.513201 \pm 8$ \\
2R-1, 60-65 & Basaltic dike & $0.513118 \pm 5$ \\
2R-2, 95-100 & Basaltic dike & $0.513123 \pm 5$ \\
19R-1, 49-55 & Basaltic dike & $0.513095 \pm 6$ \\
147-894F- & & \\
3R-1, 123-128 & Basaltic dike & $0.513151 \pm 7$ \\
Average of dikes & & $0.513134 \pm 41$ \\
& &
\end{tabular}

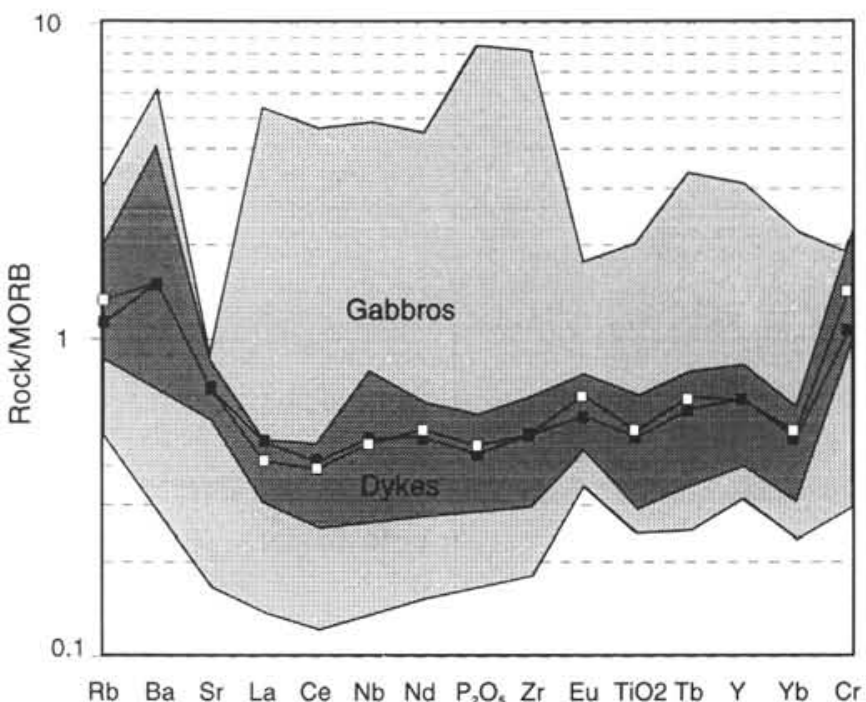

Figure 13. MORB-normalized trace element patterns of basaltic and gabbroic rocks from Holes 894F and 894G. Symbols as in Figure 1.

Site 894 (with $4-5 \mathrm{ppm} \mathrm{Nd}$ ) is used as the parental magma, then the $2-4 \mathrm{ppm}$ of $\mathrm{Nd}$ in the gabbroic rocks would suggest that the gabbros contained significant amounts of trapped liquid. If, on the other hand, an undepleted East Pacific Rise basalt with $15 \mathrm{ppm} \mathrm{Nd}$ is used, then the result would be the opposite. There are, however, good reasons to believe that the parental magma of the gabbro had a trace element signature similar to that of the crosscutting dikes. Assuming such a composition and equilibrium crystal-liquid mixing, it is clear from Figure 17 that the amount of trapped liquid in the typical gabbros should range from about $30 \%$ to $100 \%$. This suggests that the gabbros recovered at Site 894 represent mesocumulates, orthocumulates, and gabbros that are effectively frozen liquids (basaltic gabbros).

\section{Roof vs. Bottom Crystallization}

In fossil intracratonic magma chambers, one commonly sees a transition from orthocumulates to adcumulates with increasing stratigraphic height within the main layered series (Wager and Brown, 1968; Morse, 1969), and in some cases, a lateral transition from adcumulates to orthocumulates toward the margin of the intrusion (Campbell et al., 1970). In ophiolites, the lower layered parts of the
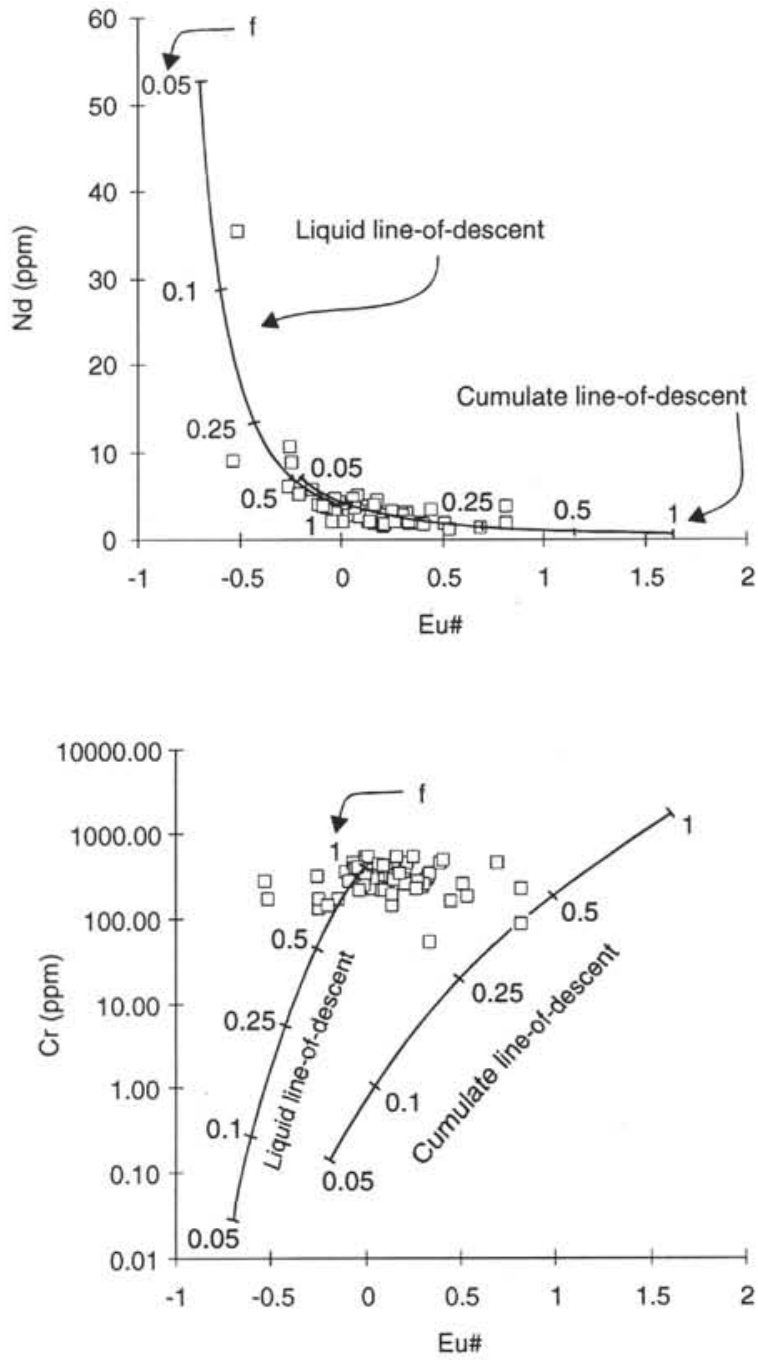

Figure 14. Variation of $\mathrm{Nd}$ and $\mathrm{Cr}$ vs. Eu\# of the gabbroic rocks shown together with liquid and cumulate lines of descent calculated assuming fractional crystallization; $f=$ the fraction of liquid remaining. Based on normative data, the following modal composition was assumed for the fractionate: $52 \%$ plagioclase, $31 \%$ clinopyroxene, $15 \%$ orthopyroxene, and $2 \%$ olivine. Partition coefficients were taken from Rollinson (1993), except $\mathrm{Cr}$ from Cox et al. (1979), and the following numbers were used. Plagioclase: Nd, 0.09; $\mathrm{Sm}, 0.072$; Eu, 0.9; Gd, 0.071; Cr, 0.01. Clinopyroxene: Nd, 0.23; Sm, 0.44; Eu, 0.47; Gd, 0.55; Cr, 10. Orthopyroxene: Nd, 0.03; Sm, 0.05; Eu, 0.05; Gd, 0.09; Cr, 2.0. Olivine: Nd, 0.0059; Sm, 0.007; Eu, 0.0074; Gd, 0.01; Cr, 0.2. See text for discussion. Symbols as in Figure 1.

plutonic sections are almost exclusively made up of adcumulates, whereas gabbros containing more trapped liquid are present in the upper parts where they are associated with basaltic gabbros (Pedersen and Malpas, 1984; R.J. Pedersen, unpub. data). The gabbros recovered at Site 894 are similar to the varitextured gabbros with respect to composition and texture as well as the presence of interstitial minerals such as apatite and zircon. This is further supported by the fact that the Site 894 gabbros are cut by basaltic dikes that exhibit similar trace element and isotope signatures. Metamorphic mineralogy and stable isotope data show that there is a metamorphic break between the gabbros and the crosscutting dikes (see Lécuyer et al., this volume). Such a metamorphic break would, however, be expected to form at this crustal level owing to brittle fracturing and subsequent rapid cooling and metamorphism induced by hydrothermal circulation. 

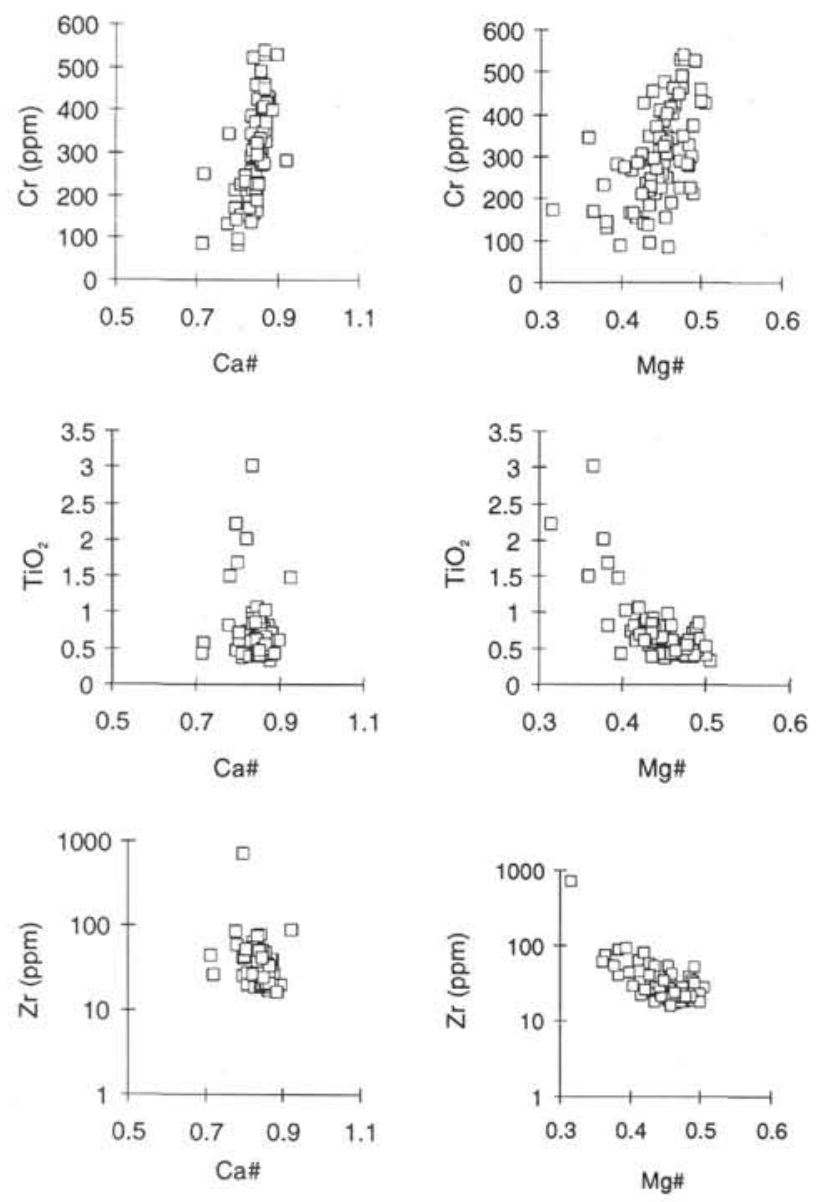

Figure 15. Variation in $\mathrm{Cr}, \mathrm{TiO}_{2}$, and $\mathrm{Zr}$ vs. Ca\# and $\mathrm{Mg} \#$. See text for discussion.

\section{Migration of Interstitial Melts during Crystallization}

Cumulate maturation, expulsion of interstitial melts, and formation of adcumulates have been suggested to result from processes such as:

1. Compaction of the crystal mush under its own weight (Irvine, 1980);

2. Convective circulation of intercumulus liquid (Morse, 1969; Hess, 1972; Tait et al., 1984; Kerr and Tait, 1986);

3. Thermal diffusion (Buchwald et al., 1985; Lesher and Walker, 1988); and

4. Synmagmatic deformation (Dick et al., 1991).

If intercumulus liquids are to be transported back into the magma reservoir owing to compaction of the crystal mush under its own weight, the crystallization must take place along the floor of the magma chamber (assuming that the crystalline rock is denser than the magma). If, however, the crystallization takes place along the roof, a reverse density gradient will develop (with crystal mush overlaying less dense magma). This unstable situation may result in stoping of the partly crystalline roof-rocks into the magma reservoir. The reverse density gradient will also prohibit any gravity-driven compaction in gabbros forming along the roof. This simple relation may explain why adcumulates are present in the lower parts and varitextured gabbros (mesocumulates, orthocumulate, basaltic gabbros) are present in the uppermost parts of fossil oceanic magma chambers exposed within ophiolite complexes. The high content of trapped inter-

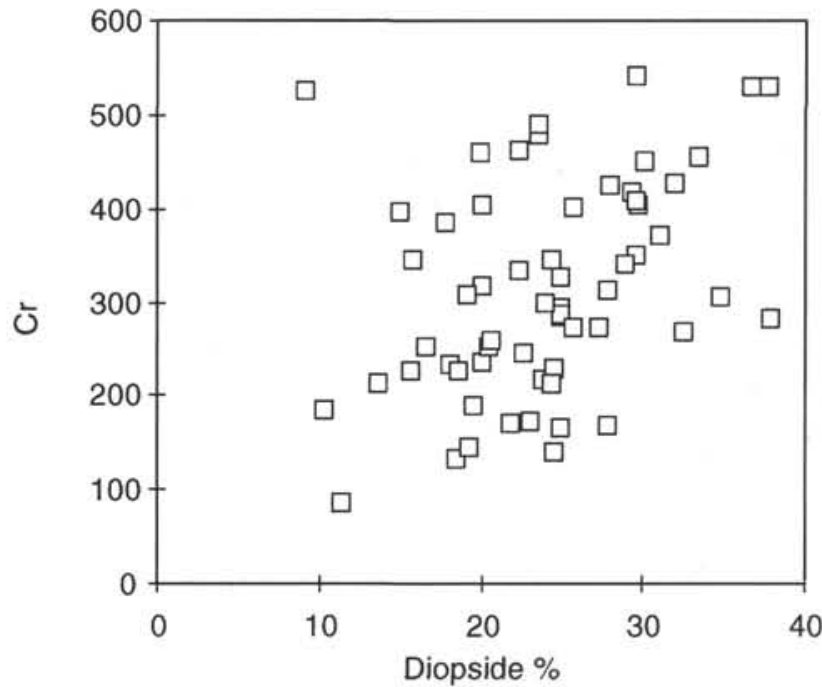

Figure 16. Variation in $\mathrm{Cr}$ vs. normative diopside content. Symbols as in Figure 1.

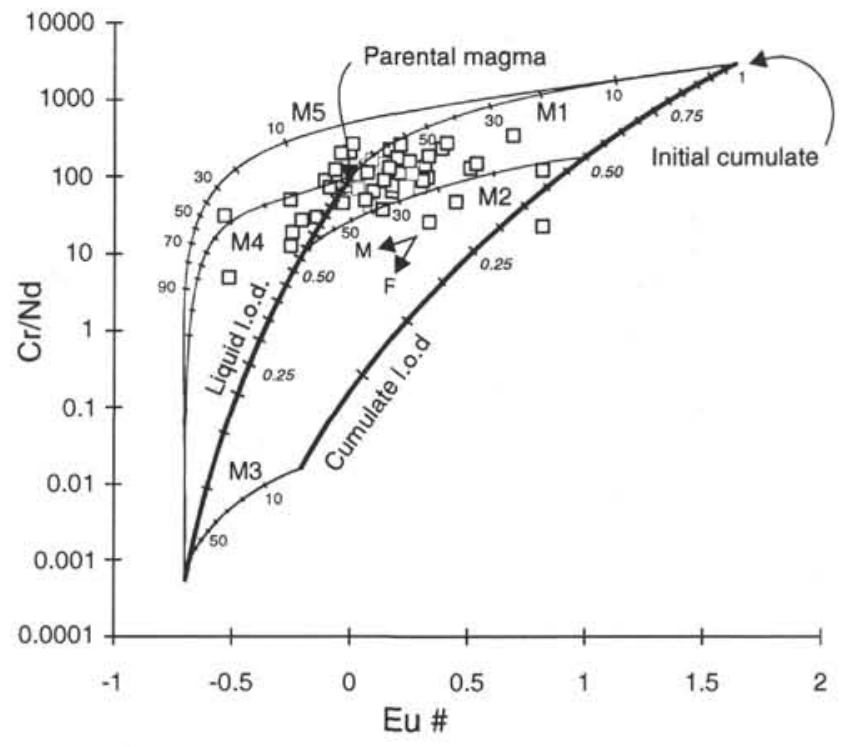

Figure 17. Variation in $\mathrm{Cr} / \mathrm{Nd}$ ratio vs. Eu\# of the gabbroic rocks shown together with liquid and cumulate lines of descent calculated assuming fractional crystallization. M1, M2, and M3 represent equilibrium mixing lines (i.e., mixing between liquid and crystals in equilibrium with the melt) for the parental magma (M1), a moderately evolved magma (50\% crystallization, or $f=0.5)(M 2)$, and a highly evolved magma $(f=0.05)(M 3)$. M4 represents the mixing line for mixing of parental magma and a highly evolved melt, and M5 represents a disequilibrium crystal-liquid mixing line for the mixing of a highly evolved magma with the initial cumulate. The numbers on M4 and M5 show the amount of evolved liquid in the mixture (in \%), and those on M1, M2, and M3 show the amount of liquid in the crystal-liquid mix. See Figure 14 for partition coefficients and modal abundances used for the modeling. Symbols as in Figure 1.

stitial liquid in the gabbroic rocks from Site 894 would, according to this theory, be consistent with their formation along the roof of the magma chamber.

Late magmatic deformation of the crystalline matrix is suggested to have played a major role in removing interstitial melts during the formation of the gabbros recovered during Leg 118 to the Atlantis Fracture Zone. The gabbros sampled from Hess Deep do not show the 
high-temperature deformation fabrics typical for the gabbros cored in Hole 735B (see Dick et al., 1991). They do, however, locally exhibit fabrics interpreted to have formed as a result of magmatic deformation. These magmatic fabrics are, in places, accompanied by a decrease in the modal abundance of poikilitic orthopyroxene in the rocks, which may suggest that interstitial melt was removed from the deformed areas (Gillis, Mével, Allan, et al., 1993). The synmagmatic fabric are frequently present along the margins of dike- or channellike bodies of equigranular gabbronorite that were found in the cored sections and interpreted by the shipboard party to represent intrusions (Gillis, Mével, Allan, et al., 1993). These equigranular bodies are slightly more evolved than the surrounding rocks and they may represent intrusive bodies or dikes that formed from segregated interstitial melts.

\section{PETROGENETIC MODEL}

We suggest the following petrogenetic evolution for the Site 894 rocks.

1. Formation of a crystal mush along a crystallizing front.

2. Upward migration of interstitial melts as a result of buoyancy. This flux of interstitial melts leads to the formation of gabbroic rocks with varying cumulate affinity (i.e., ranging from mesocumulates to basaltic gabbros). The process results in meterscale variations in cumulate affinity observed as abrupt fluctu-

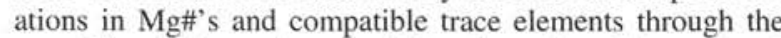
core. The gabbronorite veins/dikes formed at this stage and may represent major channel ways for the escaping melts. The net loss of interstitial melt out of the cored region can be estimated to be of the order $25 \%-50 \%$.

3. Migration of highly evolved late magmatic liquids from below and into the almost crystallized matrix. These liquids gave rise to local enrichments in incompatible elements, but had little or no effect on the distribution of compatible elements and most of the major elements.

4. Crystallization of the last fractions of interstitial melts followed by brittle fracturing, hydrothermal circulation, and metamorphism.

5. Intrusion of basaltic dikes that were derived from the same or a related magma chamber.

The geochemistry of the Site 894 gabbros is convoluted. The formation of these rocks can nevertheless in principle be explained by a simple model (i.e., the escape of interstitial melt, followed by a reinvasion of the crystalline matrix by highly evolved fluids). There are some features of the rocks that may indicate that more complex and less widely known processes, such as thermal migration, operated during their formation. The above mechanisms are, however, not mutually contradictory and may have operated together.

The Site 894 rocks have clearly provided a series of important observations that add significantly to our understanding of processes taking place within spreading-related magma chambers.

\section{ACKNOWLEDGMENTS}

We wish to thank all shipboard participants for an interesting time aboard JOIDES Resolution. We thank Tony Kemp at the University of Bristol for help with performing the REE analyses, and Hildegunn Almelid at the University of Bergen for help with XRF analyses. Paul Browning, Peter Meyer, and Richard Naslund provided substantial help in improving the manuscript. This work was supported by the NFR (RBP) and NCERC (JM).

\section{REFERENCES}

Autio, L.K., and Rhodes, J.M., 1983. Costa Rica Rift Zone basalts: geochemical and experimental data from a possible example of multistage melting. In Cann, J.R., Langseth, M.G., Honnorez, J., Von Herzen, R.P., White, S.M., et al., Init. Repts. DSDP, 69: Washington (U.S. Govt. Printing Office), 729-745.

Autio, L.K., Sparks, J.W., and Rhodes, J.M., 1989. Geochemistry of Leg 111 basalts: intrusive feeders for highly depleted pillows and flows. In Becker, K., Sakai, H., et al., Proc. ODP, Sci. Results, 111: College Station, TX (Ocean Drilling Program), 3-16.

Buchwald, V.F., Kjer, T., and Thorsen, K.A., 1985. Thermal migration, I: Or how to transport iron sulfide in solid iron meteorites. Meteoritics, 20:617-618.

Campbell, I.H., McCall, G.J.H., and Tyrwhitt, D.S., 1970. The Jimberlana Norite, Western Australia - a smaller analogue of the Great Dike of Rhodesia. Geol. Mag., 107:1-12.

Coish, R.A., and Taylor, L.A., 1979. The effects of cooling rate on texture and pyroxene chemistry in DSDP Leg 34 basalts: a microprobe study. Earth Planet. Sci. Lett., 42:389-398.

Cox, K.G., Bell, J.D., and Pankhurst, R.J., 1979. The Interpretation of Igneous Rocks: London (Allen and Unwin).

Dick, H.J.B., Meyer, P.S., Bloomer, S., Kirby, S., Stakes, D., and Mawer, C., 1991. Lithostratigraphic evolution of an in-situ section of oceanic Layer 3. In Von Herzen, R.P., Robinson, P.T., et al., Proc. ODP. Sci. Results, 118: College Station, TX (Ocean Drilling Program), 439-538.

Gamble, R.P., and Taylor, L.A., 1980. Crystal/liquid partitioning in augite: effects of cooling rate. Earth Planet. Sci. Lett., 47:21-33.

Gillis, K., Mével, C., Allan, J., et al., 1993. Proc. ODP, Init. Repts., 147: College Station, TX (Ocean Drilling Program).

Hebert, R., Constantin, M., and Robinson, P.T., 1991. Primary mineralogy of Leg 118 gabbroic rocks and their place in the spectrum of oceanic mafic igneous rocks. In Von Herzen, R.P., Robinson, P.T., et al., Proc. ODP. Sci. Results, 118: College Station, TX (Ocean Drilling Program), 3-20.

Hekinian, R., Thompson, G., and Bideau, D., 1989. Axial and off-axis heterogeneity of basaltic rocks from the East Pacific Rise at $12^{\circ} 35 \mathrm{~N}-$ $12^{\circ} 51^{\prime} \mathrm{N}$ and $11^{\circ} 26^{\circ} \mathrm{N}-11^{\circ} 30^{\circ}$ N. J. Geophys. Res., 94:17437-17463.

Hess, G.B., 1972. Heat and mass transfer during crystallization of the Stillwater igneous complex. Mem.-Geol. Soc. Am., 132:503-520.

Irvine, T.N., 1980. Magmatic infiltration metasomatism, double-diffusive fractional crystallization, and adcumulus growth in the Muskox intrusion and other layered intrusions. In Hargraves, R.B. (Ed.), Physics of Magmatic Processes: Princeton, NJ (Princeton Univ. Press), 325-384.

Kerr, R.C., and Tait, S.R., 1986. Crystallization and compositional convection in a porous medium with application to layered igneous intrusions. $J$. Geophys. Res., 91:3591-3608.

Lesher, C.E., and Walker, D., 1988. Cumulate maturation and melt migration in a temperature gradient. J. Geophys. Res., 93:10295-10311.

Malpas, J., 1990. Crustal accretionary processes in the Troodos ophiolite, Cyprus: evidence from field mapping and deep crustal drilling. In Malpas, J., Moores, E.M., Panayiotou, A., and Xenophontos, C. (Eds.), Ophiolites: Oceanic Crustal Analogues. Cyprus Geol. Surv. Publ., 65-74

Morse, S.A., 1969. Geology of the Kiglapait layered intrusion, Labrador. Mem.-Geol. Soc. Am., 12.

Natland, J.H., Meyer, P.S., Dick, H.J.B., and Bloomer, S.H., 1991. Magmatic oxides and sulfides in gabbroic rocks from Hole 735B and the later development of the liquid line of descent. In Von Herzen, R.P., Robinson, P.T., et al., Proc. ODP, Sci. Results, 118: College Station, TX (Ocean Drilling Program), 75-112.

Nicolas, A., Reuber, I., and Benn, K., 1988. A new magma chamber model based on structural studies in the Oman ophiolite. Tectonophysics, 151:87-105.

Pedersen, R.B., 1986. The nature and significance of magma chamber margins in ophiolites: examples from the Norwegian Caledonides. Earth Planet. Sci. Lett., 77:100-112.

Pedersen, R.B., and Malpas, J., 1984. The origin of oceanic plagiogranites from the Karmoy ophiolite, Western Norway. Contrib. Mineral. Petrol., $88: 36-52$.

Richard, P., Shimizu, N., and Allègre, C.J., 1976. ${ }^{143} \mathrm{Nd} /{ }^{143} \mathrm{Nd}$, a natural tracer: an application to oceanic basalt. Earth Planet. Sci. Lett., 31:269278.

Rollinson. H.R., 1993. Using Geochemical Data: Evaluation, Presentation, Interpretation: Harlow, England (Longman Scientific \& Technical). 
Tait, S.R., Huppert, H.E., and Sparks, R.S.J., 1984. The role of compositional convection in the formation of adcumulate rocks. Lithos, 17:139 146.

Von Herzen, R.P., Robinson, P.T., et al., 1991. Proc. ODP, Sci. Results, 118 : College Station, TX (Ocean Drilling Program).
Wager, L.R., and Brown, G.M., 1968, Layered Igneous Rocks: London (Oliver and Boyd).

Date of initial receipt: 12 August 1994

Date of acceptance: 21 February 1995

Ms 147S-001

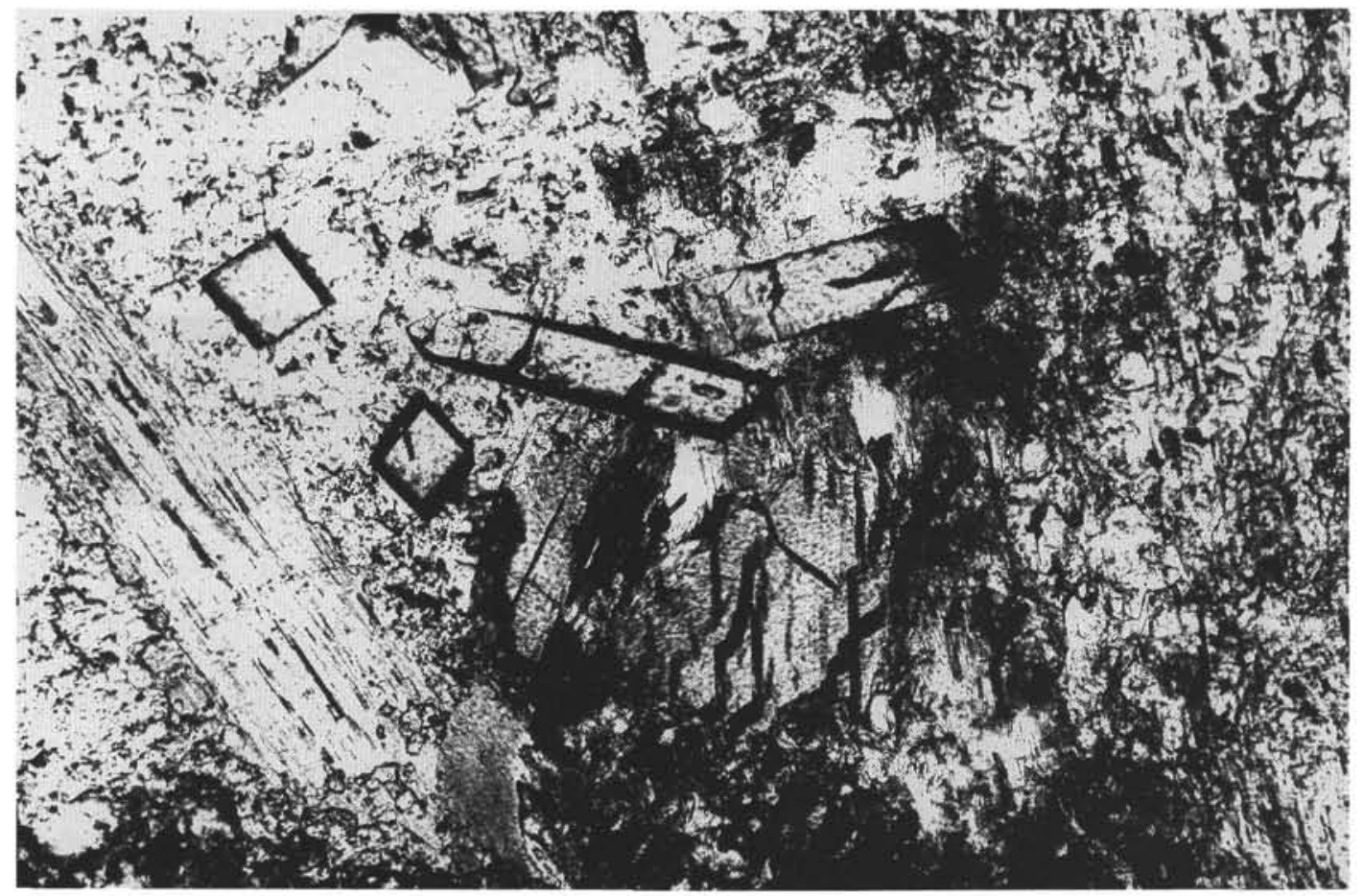

Plate 1. Euhedral zircon in coarse, pegmatitic gabbronorite (Sample 147-894G-9R-3 [Piece 4, 48-50 cm]). Field of view is $1.5 \mathrm{~mm}$.

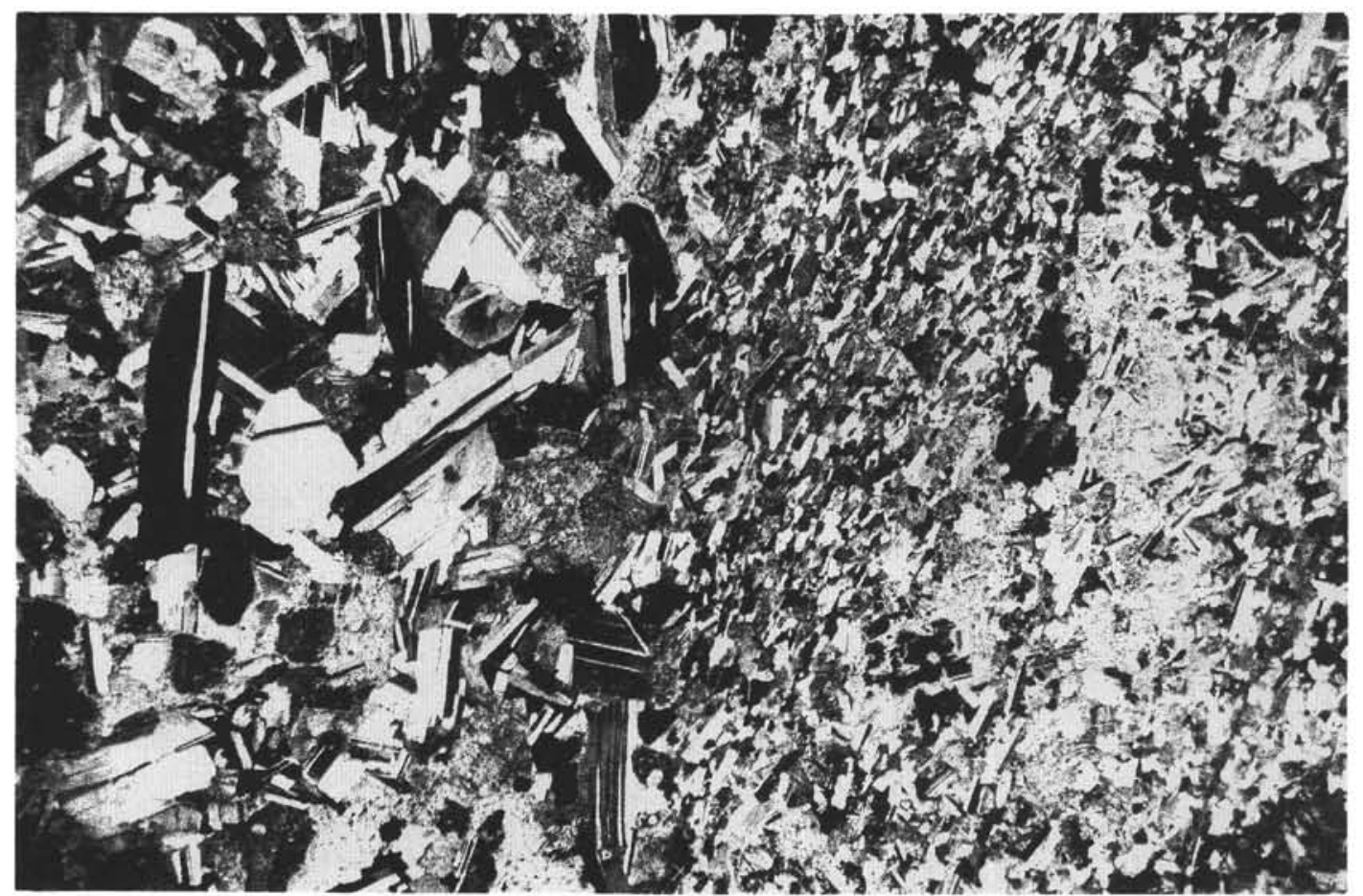

Plate 2. Magmatic foliation, defined by parallel alignment of tabular plagioclase in medium-grained gabbro, cut by coarse gabbronorite vein (Sample 147$894 \mathrm{G}-12 \mathrm{R}-2$ [Piece 9, 91-96 cm]). Field of view is $2 \mathrm{~cm}$. 


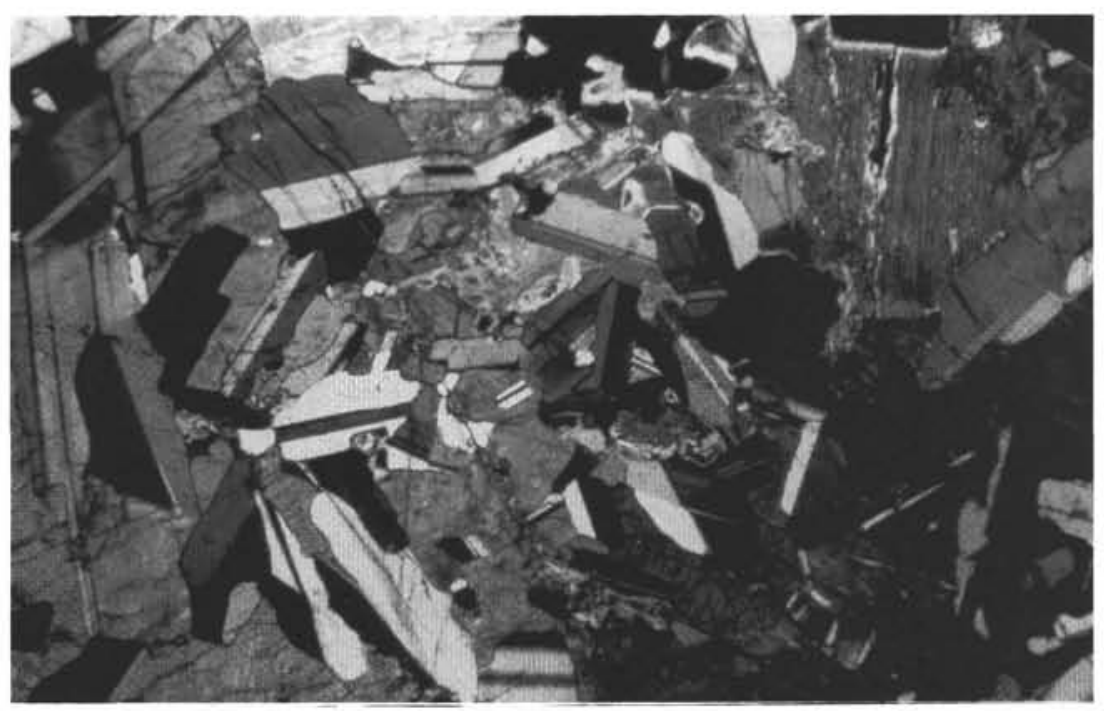

Plate 3. Photomicrograph of patches of local sub-ophitic texture in coarse poikilitic gabbronorite (Sample 147-894G-6R-1 [Piece 4A, 26-28 cm]).

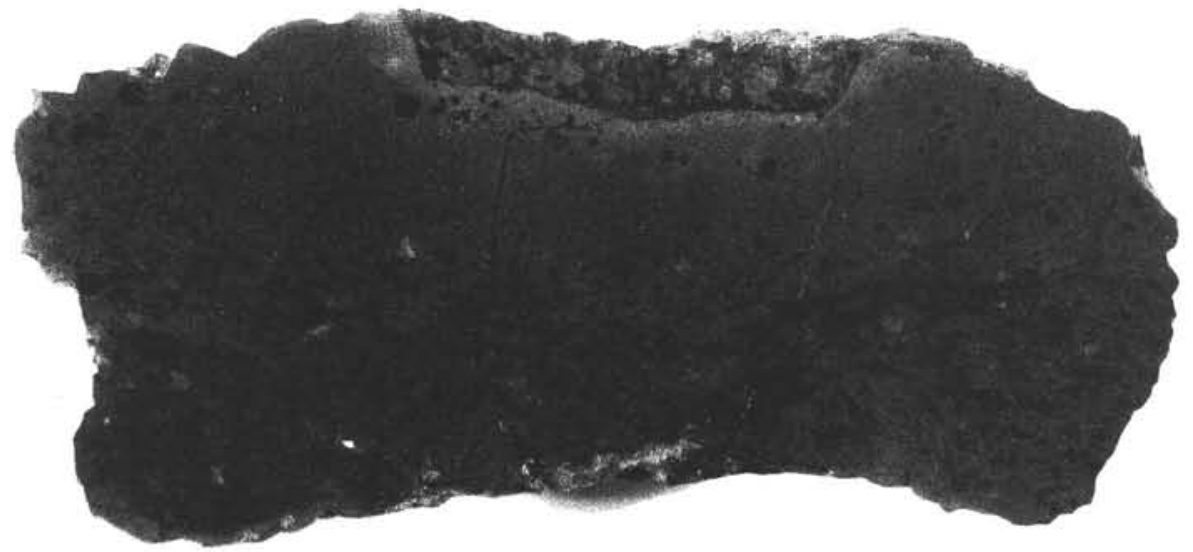

Plate 4. Primary igneous contact between gabbronorite and chilled glassy basaltic dike (Sample 147-894G-19R-1 [Piece 12, 70-84 cm]). 

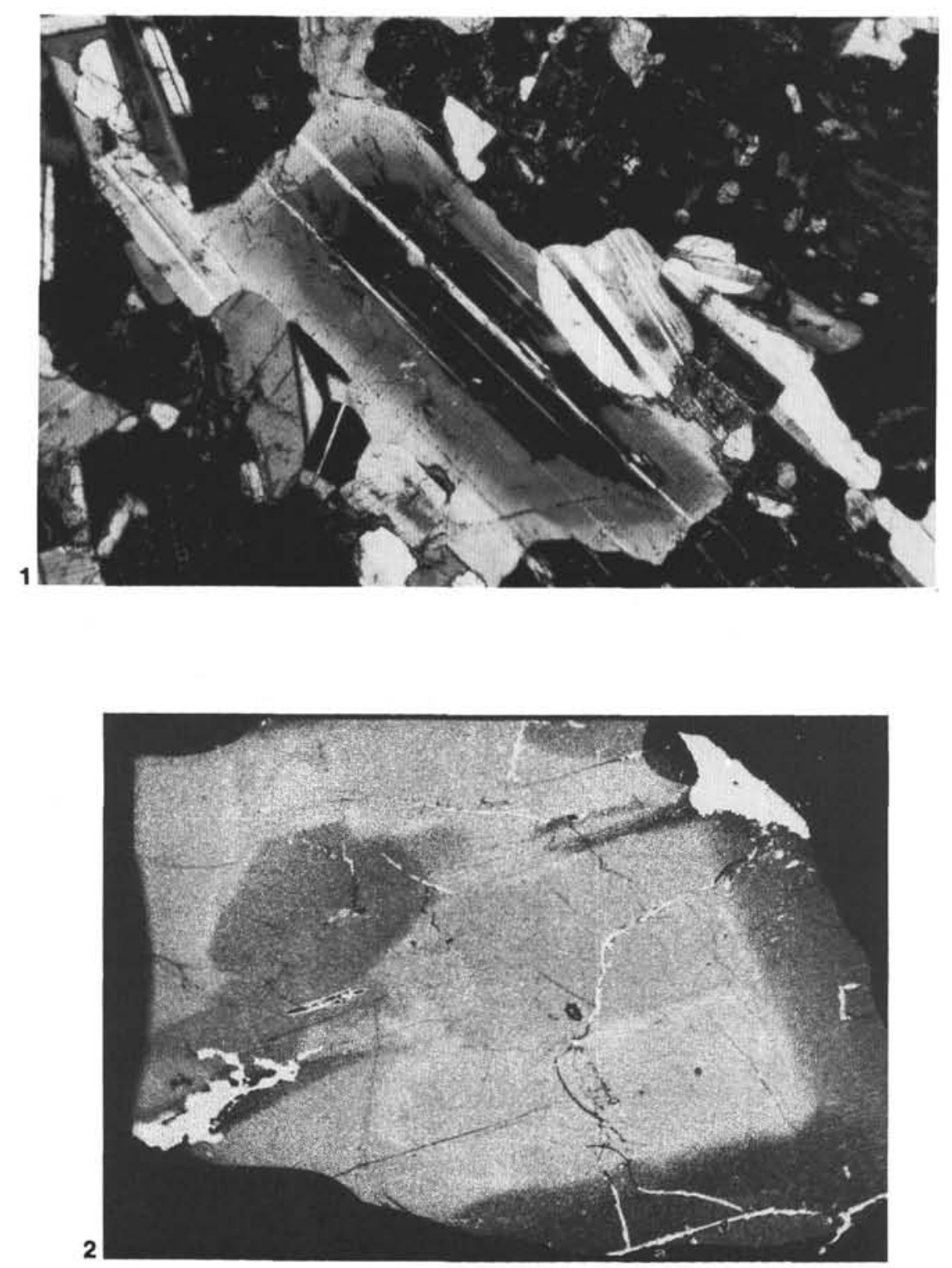

Plate 5. 1. Photomicrograph of zoned plagioclase and euhedral zircon in pegmatitic gabbronorite (Sample 147-894G-9R-3 [Piece 5C, 71-77 cm]). Field of view is $2 \mathrm{~mm}$. 2. Backscatter image of patchy zoning in plagioclase, same sample. 